\title{
Paying a Visit: The Dalai Lama Effect on International Trade
}

Andreas Fuchs and Nils-Hendrik Klann December 2010

CWPE 1103

Paper presented at Silvaplana 2010 19th Workshop on Political Economy, July 2010 


\title{
Paying a Visit: The Dalai Lama Effect on International Trade ${ }^{1}$
}

\author{
Andreas Fuchs ${ }^{2}$ and Nils-Hendrik Klann ${ }^{3}$
}

December 2010

\begin{abstract}
The Chinese government frequently threatens that meetings between its trading partners' officials and the Dalai Lama will be met with animosity and ultimately harm trade ties with China. We run a gravity model of exports to China from 159 partner countries between 1991 and 2008 to test to which extent bilateral tensions affect trade with autocratic China. In order to account for the potential endogeneity of meetings with the Dalai Lama, the number of Tibet Support Groups and the travel pattern of the Tibetan leader are used as instruments. Our empirical results support the idea that countries officially receiving the Dalai Lama at the highest political level are punished through a reduction of their exports to China. However, this 'Dalai Lama Effect' is only observed for the Hu Jintao era and not for earlier periods. Furthermore, we find that this effect is mainly driven by reduced exports of machinery and transport equipment and that it disappears two years after a meeting took place.
\end{abstract}

Keywords: International Trade, International Political Economy, Diplomatic Relations, Exports to China, Tibet, Dalai Lama

JEL codes: F13, F51, F59

\footnotetext{
${ }^{1}$ The authors thank Axel Dreher, Stephan Klasen, the "Göttingen Trade Group" and participants at the Göttingen Workshop International Economic Relations, at the Beyond Basic Questions Workshop at Aarhus Business School, at the Silvaplana Workshop of Political Economy and at the Annual Conference of the European Trade Study Group for valuable comments on earlier drafts. Excellent research assistance was provided by Hendrik van Broekhuizen, Juliane Kästner, and Katharina Richert.

${ }^{2}$ University of Goettingen, Faculty of Economic Sciences, Platz der Goettinger Sieben 3, D-37073 Goettingen, Germany, E-Mail: afuchs@uni-goettingen.de

${ }^{3}$ University of Goettingen, Faculty of Economic Sciences, Platz der Goettinger Sieben 3, D-37073 Goettingen, Germany, E-Mail: hhk@uni-goettingen.de
} 
"We will take corresponding measures to make the relevant countries realise their mistakes."

Zhu Weiqun, executive deputy head of the Communist party's United Front Work Department

"There is a Tibetan saying: some wounds in the mouth recover by themselves."

Tendzin Gyatsho, $14^{\text {th }}$ Dalai Lama

\section{Introduction}

The Chinese autonomous region of Tibet is an area of great economic and geo-strategic significance as it holds considerable amounts of natural resources and connects China to South and Central Asia. In addition, Tibet is known as 'Asia's water tower' since important rivers such as the Mekong, Yangtze and Yellow river originate in the region. Tibet's political status represents a long-run cause of conflict both in China and in international relations that revolve around the question of whether the incorporation of Tibet into China was in accordance with international law. ${ }^{4}$ China considers the status of Tibet as an internal affair, in which outside interference is rejected. As Goldstein (1998) notes, international opinion plays an important role in conflicts over regional independence since "the ambiguity about when entities have the right to seek self-determination has made international opinion an important dimension of such disputes" (p. 83). In light of this, the Chinese administration has recognized that its position on Tibet's status not only needs to be enforced domestically, but also internationally. ${ }^{5}$ By opposing any notion from abroad that might challenge the status-quo of the region, China not only aims to contain the spread of unrest inside Tibet, but also seeks to weaken the worldwide Tibetan independence movement.

Within this context, the Dalai Lama, in his position as leader of the Tibetan community, is seen as a threat to the integrity of the Chinese nation. Consequently, meetings of foreign officials with the Dalai Lama are a constant source of bilateral diplomatic tensions with China. In addition to purely diplomatic threats, China more-or-less openly threatens that it will respond to meetings between its trading partners' officials and the Tibetan leader with measures that will result in a deterioration of their trade relationships. An article published in

\footnotetext{
${ }^{4}$ See Goldstein (1997) for a historical overview on the so-called 'Tibet Question', i.e., the long-lasting conflict over the political status of Tibet.

${ }^{5}$ According to an official government bulletin, China identifies the issue of Tibet as one of the "most important and sensitive" core issues to be respected by China's partners (available at: http://www.gov.cn/misc/200905/27/content 1326253.htm).
} 
China Daily - a state-run newspaper, known as a mouthpiece of the Communist party clearly advises against outside interference in the Tibet question "if they [countries] want to remain on good terms with China." 6 The government's decisiveness on this matter is reflected in instances such as the prominent case of France, where the country was crossed off the travel agenda of two Chinese trade delegations in 2009 in retaliation to a meeting between French president Nicolas Sarkozy and the Dalai Lama. In an interview conducted in 2007, the Dalai Lama himself acknowledged the unwillingness of state officials to receive him, so as not to jeopardize the intense economic ties that their countries have established with China. ${ }^{7}$ Beyond existing anecdotal evidence, no empirical analysis has, to the best of our knowledge, thus far been conducted to unveil whether China responds to meetings between its trading partners and the Dalai Lama with any systematic economic punishment. This paper aims to fill this gap. Moreover, results may offer valuable insights to which extent political relations matter for trade with (autocratic) emerging economies.

The role of political determinants of trade is currently in the focus of the literature (e.g, Aidt and Gassebner 2010, Gassebner, Keck and Teh 2010, Kastner 2007, Méon and Sekkat 2008, Nitsch and Schumacher 2004). Previous research has shown that the bilateral political climate plays an important role in trade relationships (e.g., Pollins 1989, Morrow, Siverson and Taberes 1998). Also, diplomatic exchanges between trading partners foster bilateral trade through diplomatic representations (Rose 2007) and state visits (Nitsch 2007). The state of political relations between China and its trading partners is likely to be even more important as a determinant of bilateral trade than it is in the case of trade between free market economies. Whilst prices and other product characteristics should - at least in theory - be the sole determinants of import decisions in a market system, the Chinese government exerts additional influence on commercial activity. In this regard, Aidt and Gassebner (2010) show theoretically and empirically that a country's involvement in international trade differs between democracies and autocracies. Since China is neither a democracy, nor a free market economy, its administration has greater capacity to impact on trading decisions than the government in a democratic free market economy. Such significant scope for government intervention thus gives leeway for the utilization of trade flows as foreign policy tool. Since a country's policy towards the Dalai Lama influences its bilateral relations with China and may provoke retaliatory responses from Beijing, we hypothesize that a trade-deteriorating effect is caused by foreign officials receiving the Dalai Lama.

\footnotetext{
6 "Wrong stance on Tibet hinders ties with China," China Daily, March $5^{\text {th }} 2009$, available at: http://www.chinadaily.com.cn/china/2009-03/05/content 7538147.htm

7 "Dalai Lama Visit Jeopardizes German Business Interests", Spiegel Online, October $17^{\text {th }} 2007$, available at: http://www.spiegel.de/international/world/0,1518,506166,00.html.
} 
We run a gravity model of exports to China from 159 partner countries between 1991 and 2008 to test for political influences on China's trading decisions. The paper analyzes whether countries that receive the Dalai Lama are economically punished by the Chinese through a reduction of their exports to China. It is also tested whether the size of the punishment increases with the rank of the highest official receiving the Tibetan leader and how the effect evolves over time. Furthermore, we provide results when controlling for the potential endogeneity of meetings with the Dalai Lama and show results based on disaggregated trade data to deepen our understanding of what we call the 'Dalai Lama Effect'.

Our empirical results confirm the existence of a negative effect of Dalai Lama receptions at the highest level on exports to China for the Hu Jintao era (2002-2008). Meetings of a head of state or head of government with the Dalai Lama lead to a reduction of exports to China by $8.1 \%$ or $16.9 \%$ on average, depending on the estimation technique used. This effect is mainly driven by reduced exports of machinery and transport equipment and it disappears in the second year after a meeting took place.

The paper is structured as follows: Section 2 provides an overview on the literature regarding the link between bilateral political relations and international trade to get insights how meetings with the Dalai Lama might adversely affect trading relationships. In Section 3, we present anecdotal evidence illustrating how the bilateral climate between China and its trading partners deteriorates after foreign officials' meetings with the Tibetan leader and formulate our hypotheses. Section 4 presents the empirical approach, the data used and the empirical results, which show whether countries officially receiving the Dalai Lama are economically punished through trade reductions. Finally, Section 5 summarizes our findings and concludes.

\section{Political influences on trade and the 'Dalai Lama Effect'}

While pure economic theory suggests that economic actors base their trading decisions entirely on intrinsic characteristics of goods and services such as price, quantity and quality, political relations exert additional influence on trade. In this regard, trade ties can be exploited as a foreign policy tool by governments to influence political decisions of trading partners. As such, by manipulating trade flows, a country can exploit the trade dependency of its trading partners in order to force their governments to abide by its political viewpoints. Bilateral trade flows can thus be used as an instrument of political pressure and leverage against countries with conflicting interests (Hirschman 1945, Baldwin 1985). Hereby, the degree of political compliance that can be induced by the dominant country increases with the asymmetry of the trade interdependency between the two trading partners (Keohane and 
Nye 1977, Richardson and Kegley 1980). With the rapidly increasing size of the Chinese economy, the asymmetry of trade dependencies between China and its trading partners shifts in China's favor. This development enables China to enforce political compliance among its trading partners to an increasing extent.

Several theoretical concepts provide an explanation why politics matters for bilateral trade relationships. Pollins (1989) has developed a public choice model of bilateral trade flows. Extending the concept of welfare to include political ties, import decisions are influenced by the place of origin of the traded goods and services. Based on security concerns, risk-averse importers reward political friends and punish adversaries. Regarding hostile relationships between countries, Gowa and Mansfield (1993) argue that gains from trade are the source of security externalities as trade-induced efficiency frees resources for military use in the economy of the trading partner. Consequently, it is in a country's strategic interest to concede such gains exclusively to befriended countries and deny them to enemies. States may thus rely on trade interdependencies to strategically reward allies or punish adversaries. Furthermore, Kastner (2007) argues that states may disrupt trade with their partners in order to signal resolve in a bilateral disagreement they may have with their trading partners over matters unrelated to trade.

Prior empirical analyses have confirmed that the state of bilateral political relations affects international trade. A first strand in the literature focuses on the conflict-trade nexus and analyzes the role of bilateral climate on trade relationships. While some literature on the link between military conflicts and trade exists (e.g., Glick and Taylor 2005, Keshk, Pollins and Reuveny 2004, Martin, Mayer and Thoenig 2008, Oneal, Russet and Berbaum 2003), conflicts do not need to be militarized in order to influence trade flows. An anticipated conflict alone might trigger reductions of bilateral trade due to "the threat of future government action to restrict trade" (Morrow, Siverson and Taberes 1998, p. 650). Exploiting bilateral event data on conflict and cooperation for the period 1955-1978, Pollins' (1989) empirical results support the hypothesis that greater amity between trading partners increases trade while greater hostility has a trade-reducing effect. Gowa and Mansfield (1993) also find that alliances between trading partners foster bilateral trade. ${ }^{8}$ Combining both approaches, Morrow, Siverson and Taberes (1998) find that joint democracy and common interests of commercial partners increase bilateral trade between commercial partners whereas no effect is found for conflicts and alliances between countries. In a more recent study, Kastner (2007) finds evidence that the trade-reducing impact of bad bilateral political relations is reduced if internationalist economic interests are strong, which is proxied by low trade barriers.

\footnotetext{
${ }^{8}$ Incorporating new trade theory, empirical evidence in Gowa and Mansfield (2004) suggests that alliances (and other measures of bilateral relations) are more important factors in trade under increasing returns to scale than under constant returns to scale.
} 
More tangible than the abstract concept of bilateral climate, a second strand in the literature on the link between bilateral political relations and international trade finds that diplomatic exchanges among trading partners foster bilateral trade through diplomatic representations and state visits. Analyzing export flows from 22 countries for 2002 and 2003 in a gravity framework, Rose (2007) finds that the size of a country's diplomatic service has a positive impact on its exports: each additional consulate leads to an increase of exports by about six to ten percent. Focusing on export flows of 17 Spanish regions for 1995-2003, Gil-Pareja, Llorca and Martínez Serrano (2008) find that Spanish regional trade agencies abroad have a positive impact on exports. This effect is even greater than the export-promoting impact of Spanish embassies and consulates situated in the respective partner countries. Most relevant to our study, Nitsch (2007) finds empirical evidence that state and official visits do have a trade-increasing effect. Estimating export flows from France, Germany and the United States for 1948-2003, he finds that one visit is associated with an increase in exports of between eight and ten percent.

Political relations influence bilateral trade with the extent of this influence varying between political regimes "since governments in free market economies still set the rules under which firms import and export, while governments in managed economies directly negotiate the terms of trade" (Morrow, Siverson and Taberes 1998, p. 649). Thus, the influence of international politics on trading decisions is expected to be of higher importance in autocratic countries such as China than in established market democracies. As trade regulations are stricter and state-owned enterprises are of greater importance for economic activity in most emerging economies, their trading decisions are often more politically driven, turning trade ties into a transaction channel via which the political agenda of a country can be globally disseminated and enforced upon trading partners. In line with this, Mansfield, Milner and Rosendorff (2000) discuss regime differences in trade policy that emerge as the chief executive does not rely on the approval of a legislative majority in an autocracy. In a related article, Aidt and Gassebner (2010) show theoretically and empirically that governments of autocracies exert more influence on trade flows than democratic administrations, which is explained by a lack of political accountability faced by the executive of an autocratic regime.

Taken together, in the case of China, the significant scope of government influence in the Chinese economy provides the country's political leaders with all means required to manage trade in such a way that it rewards countries that adhere to China's political preferences and punishes those that do not. Since the Chinese government seeks to contain the expression of opinions that challenge the status quo of Tibet, it reacts with harsh objections to any meeting of foreign officials with the Dalai Lama, the leader of the Tibetan community. Therefore, a deterioration of the bilateral political climate and a decrease in bilateral 
diplomatic exchanges, as a result of foreign officials meeting the Dalai Lama, may lead to a systematic reduction of exports to China through government influence. For example, countries receiving the Tibetan leader might be punished directly through a reduction of trade missions and, thus, exports of goods typically purchased in the ambit of such missions. Also, tariff and non-tariff barriers might be raised and negotiations on free trade agreements might be postponed as a response to receptions of the Dalai Lama by foreign officials.

At first glance, it may seem odd that China would be willing to forgo the gains that would arise from trade under efficient importing decisions in order to punish trading partners who receive the Dalai Lama. However, China's political leadership may be willing to bear the economic and political costs that arise from diverting trade away from Dalai Lama-receiving countries if such 'punishment' increases the likelihood of its political survival. As argued in Mansfield, Milner and Rosendorff (2000), political leaders in autocratic regimes also need to maintain political support to ensure their political survival, which is also reflected in their trade policy. By exerting economic pressure on Dalai Lama-receiving countries, the Chinese administration seeks to maintain the territorial integrity of China and intends to strengthen the stability of its Communist regime in the multi-ethnic country. However, such an economic punishment mechanism will only prevail as long as the expected political gains from stabilizing the regime outweigh the losses from trade diversion.

Furthermore, in addition to direct government action, a trade-deteriorating effect of official Dalai Lama receptions may operate through consumer behavior. Prior empirical research indicates that bilateral opinions (or the affinity between nations) impact on trade as they shift consumer preferences (Disdier and Mayer 2007, Guiso, Sapienza and Zingales 2009). ${ }^{9}$ Similarly, the state of bilateral political relations between China and its trading partners might have important repercussions for consumer behavior. Since media information on foreign officials meeting with the Dalai Lama may alter public opinions towards the countries receiving the Tibetan leader, Dalai Lama receptions can be expected to affect the demand for consumption goods, most likely, that for certain symbolic goods that are characteristic of the country hosting the Dalai Lama. ${ }^{10}$

\footnotetext{
${ }^{9}$ Using Eurobarometer opinion data on the accession of Central and East European countries to the European Union, Disdier and Mayer (2007) show that 'bilateral affinity' has a trade-increasing effect. In a related study, Guiso, Sapienza and Zingales (2009) find that trade increases significantly with their measure of bilateral trust obtained from Eurobarometer surveys. Beyond its effect on trade via trust, cultural similarities seem to impact positively on trade volumes via other channels.

${ }^{10}$ For example, the disruption of the Olympic torch relay of the 2008 Beijing Olympic Games through the French capital Paris by pro-Tibet activists caused irritation among the Chinese public and subsequently sparked calls for a consumer boycott against French products.
} 


\section{Anecdotal Evidence and Hypotheses}

Official receptions of the Dalai Lama and even the mere announcement of such receptions regularly lead to diplomatic tensions between the People's Republic of China and countries hosting the Dalai Lama. Since coming into exile in 1959 until the end of 2009, the Tibetan leader visited 62 countries on all continents. ${ }^{11}$ Although the Dalai Lama himself emphasizes the non-political nature of his visits, he uses his travels as an opportunity to meet foreign politicians in order to discuss - among other issues - the situation in Tibet. The Chinese administration emphasizes that Tibet forms an integral part of China and sees the Dalai Lama as a pretentious state leader with a separatist agenda regarding Tibet. Therefore, any meeting of foreign officials with the Buddhist monk is perceived by Beijing as interference with internal affairs. Despite Chinese opposition, many countries have, to an increasing extent, recognized the Dalai Lama as a notable religious leader, subsequently granting him considerable attention. At the same time, China has increased pressure on other countries to not receive the exiled Tibetan leader in any form. In this section, we study anecdotal evidence on how the bilateral climate between China and its trading partners is influenced by foreign officials' meetings with the Dalai Lama and derive our hypotheses. ${ }^{12}$

\section{Hypothesis 1: Trade-deteriorating effect of Dalai Lama meetings}

In addition to purely diplomatic threats, China increasingly exerts economic pressure on foreign governments to discourage them from meeting with the Dalai Lama. Already in 1989, when the Dalai Lama was awarded the Nobel Peace Prize in Oslo, China threatened to cut economic ties with Norway if the Norwegian king or government attended the ceremony. ${ }^{13}$ The growing assertiveness of the Chinese administration towards foreign dignitaries' meetings with the Tibetan leader reflects China's rising economic power. As such, this growing economic power provides China with the leverage needed to advance its political interests.

The Dalai Lama was officially invited to the White House for the first time in 1991 by George Bush senior. The reception marked a pronounced change from the policy of former US

\footnotetext{
${ }^{11}$ In 1967, the Dalai Lama travelled outside India for the first time in order to visit Japan and Thailand. His first trip to Europe was in 1973 where he visited 12 countries in 75 days. In 1979, he travelled to the United States and Canada for the first time.

${ }^{12}$ Of course, the incidents of diplomatic threats listed below are not exhaustive, but provide some illustrative examples. Moreover, many diplomatic threats operate in the shadows, as can be seen in the example of a letter written by China's ambassador Zhang Yun to the Dutch Chairman of the Standing Committee on Foreign Affairs Henk Jan Ormel. In the text, which, to the surprise of the ambassador, was made public, the Chinese embassy warned that Sino-Dutch relations might be negatively affected by a planned meeting between Dutch members of parliament and the Dalai Lama ("We are clear: no dalai lama visits", NRC Handelsblad, May $7^{\text {th }} 2009$, available at: http://www.nrc.nl/international/Features/article2234645.ece/We are clear no dalai lama visits).

13 "China Threatens to Cut Ties with Norway over Nobel Award", The Associated Press, October $19^{\text {th }} 1989$.
} 
presidents and sparked immediate protest from the Chinese. ${ }^{14}$ During the subsequent two Clinton and Bush presidencies, the Dalai Lama has been a visitor to the White House a further nine times, provoking regular protest from Beijing. In 2007, the US Congress awarded the Congressional Gold Medal - the highest civil honor conferred in the United States - to the Dalai Lama. The act was compounded by the fact that the US president personally attended the award ceremony. In a statement issued one day later by the Chinese Ministry of Foreign Affairs, Spokesperson Liu Jianchao emphasized that the award "ha[d] severely hurt the feelings of the Chinese people and gravely undermined the relationship between China and the US," a wording that is characteristic of the Chinese reactions to countries officially receiving the Dalai Lama. He furthermore "urge[d] the US to take effective measures immediately to undo the severe adverse impact of its erroneous act." ${ }^{\text {15 }}$ In 2009, President Barack Obama decided not to receive the Dalai Lama. The media deemed the decision "unprecedented" and surmised that the president had strategically delayed the reception until after his state visit to Beijing. The meeting finally took place in February 2010 and caused considerable discontent in Beijing. Chinese authorities emphasized that the move damaged US-Chinese relations, which, in turn, would undermine the United States' recovery from the current economic crisis. ${ }^{16}$

Before Italian prime minister Silvio Berlusconi's reception of the Dalai Lama in 1995, the Chinese prime minister warned his Italian counterpart that "if this [the Italian] government will adopt a policy that could damage a matter of principle [for China], it may also damage trade relations." ${ }^{17}$ Facing potential trade retaliations by the Chinese, Berlusconi openly admitted to the Dalai Lama that the international community was facing a dilemma, "caught between the importance of maintaining trade relations and protecting human rights." 18 The decision to meet the Tibetan leader despite Chinese threats was judged as "courageous" by both the Italian media and the Dalai Lama himself.

In contrast, Germany's political leaders refrained for a long time from meeting with the Dalai Lama. In this regard, a 1995 New York Times article critically assessed that German foreign policy was aimed at avoiding political conflict over human rights issues with China, so as not

\footnotetext{
14 "On my mind; Beijing Heart Attack", The New York Times, April 19 ${ }^{\text {th }} 1991$, p. A27, available at: http://www.nytimes.com/1991/04/19/opinion/on-my-mind-beijing-heart-attack.html.

15 "Foreign Ministry Spokesperson Liu Jianchao's Regular Press Conference", Ministry of Foreign Affairs of the People's Republic of China, October 18 ${ }^{\text {th }}$ 2007, available at: http://www.fmprc.gov.cn/eng/xwfw/s2510/2511/t373809.htm.

${ }_{16}$ "Destiny of Tibet 'in hands of people'", China Daily, February $3^{\text {rd }} 2010$, available at: http://www.chinadaily.com.cn/china/2010-02/03/content 9417649 2.htm.

17 "Li Peng "diffida" Berlusconi; II Cavaliere l'aveva promesso a Pannella. Ma Pechino avverte: "Sono in pericolo le relazioni commerciali"', La Stampa, June $15^{\text {th }} 1994$, p. 4 , own translation.

18 ""Italia, grazie per il coraggio"; II leader tibetano a Palazzo Chigi, per la prima volta un governo italiano sfida il veto cinese", La Stampa, June $18^{\text {th }} 1994$, p. 7 , own translation.
} 
to endanger lucrative trade ties with the emerging economy. ${ }^{19}$ Bilateral discontent emerged between China and Germany when Chancellor Angela Merkel deviated from this protocol by receiving the Dalai Lama in the chancellery in 2007. Merkel's predecessor Gerhard Schröder, known for his keenness on good economic relations with China, criticized the decision as a mistake, bearing in mind the detrimental effect the meeting may have on bilateral relations with Beijing. In the forerun to the Dalai Lama's announced visit to Berlin, Chinese politicians warned that the meeting would severely damage economic ties. In the aftermath of this meeting, several other bilateral meetings at various political levels were cancelled.

Sino-French relations worsened as French government sources announced a meeting between Nicolas Sarkozy and the Dalai Lama. Chinese officials promptly insinuated that trade ties with France could suffer unless the meeting was cancelled. China sent a strong message to France, which held the EU presidency at the time, by cancelling the 11th annual EU-China summit on rather short notice..$^{20}$ In addition, the media reported that the finalization of a contract to purchase 150 passenger planes from Airbus was suddenly postponed without further explanation. After the actual meeting took place, Vice Foreign Minister He Yafei emphasized that it had "sabotage[d] the political basis of China-France and China-EU relations" and furthermore warned of "serious consequences" which France alone would have to bear. ${ }^{21}$ In early 2009 , France was crossed off the travel agenda of two Chinese trade delegations. The first delegation alone signed 15 billion US dollars' worth of trade deals in other European countries. Furthermore, Chinese Prime Minister Wen Jiabao did not pay any state visit to France during his trip to Europe in January 2009. When asked to comment on the itinerary of his European tour, he was cited saying: "I looked at a map of Europe on the plane. My trip goes around France. [...] We all know why."22

The case of Mongolia serves as a further illustration of China's antagonism towards Dalai Lama-receiving countries. The Dalai Lama has visited the country on several occasions since 1979 as the country has strong historical and cultural links with Tibet. As reported by media sources in 2002, China imposed a temporary ban on imports from Mongolia and blocked the only railway link between the two countries in response to the reception of the Tibetan leader by the Mongolian Prime Minister Nambaryn Enkhbayar. The import ban was

\footnotetext{
19 "Seeking China Deal, Bonn Shuns Rights Issue", The New York Times, July $13^{\text {th }} 1995$, available at: http://www.nytimes.com/1995/07/13/world/seeking-china-deal-bonn-shuns-rights-issue.html.

${ }_{20}$ The meeting had originally been scheduled to take place on December $1^{\text {st }}$ in France where over a hundred high-ranking Chinese politicians and business leaders would have met with their European counterparts.

21 "He Yafei Lodges a Strong Protest to France over Sarkozy's Meeting with the Dalai Lama," Ministry of Foreign Affairs of the People's Republic of China, December $12^{\text {th }} 2010$, available at: http://www.fmprc.gov.cn/eng/wjb/zzjg/xos/gjlb/3291/3293/t525570.htm.

22 "Premier: We all know why", China Daily, February $2^{\text {nd }} 2009$, available at: http://www.chinadaily.com.cn/china/2009-02/03/content 7440286.htm.
} 
lifted after only one day and no further official receptions of the Dalai Lama took place in Mongolia - despite him visiting the country again in 2006.

We thus hypothesize that a deterioration of the bilateral political climate and a decrease in bilateral diplomatic exchanges, as a result of foreign officials meeting the Dalai Lama, leads to a significant reduction in exports to China. Our first hypothesis reads as follows:

Hypothesis 1: There is a trade-deteriorating effect caused by foreign officials receiving the Dalai Lama.

Hypothesis 2: Importance of the rank of the dignitary met

Political leaders are aware that meetings with the Dalai Lama put considerable stress on countries' bilateral relations with China, and that it may also have negative implications for the economic ties between them. A first alternative to not receiving the Dalai Lama at all is to meet with him but not in official capacity as head of state. For example, when the Dalai Lama planned to visit Switzerland in 2008, Pascal Couchepin announced that he would be meeting with the religious leader not in his function as President of the Swiss Confederation but as Minister of Culture. ${ }^{23}$ Similarly, the Clinton administration, granted him the opportunity to visit the White House, even though he was formally received only by a minister and not the president himself. Despite official sources emphasizing that no formal encounter between the Dalai Lama and the US president was scheduled, Clinton nevertheless dropped in during the talks. In September 1995, a New York Times article concluded that a better treatment of the Dalai Lama "would [have] cost us [the US] trade with the Chinese."24

As a second alternative, some leaders prefer to delegate the task to lower-ranked government representatives in the hope of reducing the negative effect that such meetings may have on bilateral relations with China. Nevertheless, by employing such a strategy, the government still manages to sedate pro-Tibet lobby groups, human rights organizations and other sympathizers of the Dalai Lama. For example, during his trip to the Netherlands in 2009, the Dalai Lama was received by some members of parliament and met with the country's foreign minister during a conference between Dutch religious leaders. Prime Minister Jan Peter Balkenende, however, reportedly feared that a personal encounter with the Tibetan leader would bring "unwarranted risk" to Sino-Dutch relations. ${ }^{25} \mathrm{~A}$ similar strategy

23 "Dalai Lama sagt Besuch in der Schweiz ab", NZZ Online, September $13^{\text {th }} 2008$, available at: http://www.nzz.ch/nachrichten/schweiz/dalai lama sagt besuch in der schweiz ab 1.831028.html.

24 "On My Mind; If He Can, Can I?" The New York Times, September 15 ${ }^{\text {th }} 1995$, available at: http://www.nytimes.com/1995/09/15/opinion/on-my-mind-if-he-can-can-i.html.

${ }_{25}$ "Dalai lama meets foreign minister, but not prime minister," NRC Handelsblad, June $5^{\text {th }} 2009$, available at: http://www.nrc.nl/international/article2262841.ece/Dalai lama meets foreign minister, but not prime minister. 
seems to have been employed in Germany in 2008, exactly one year after the first reception of the Dalai Lama by a German chancellor. In what could be interpreted as giving in to Chinese pressure, high-ranking members of the German government avoided a further encounter with the Dalai Lama, referring to their "tight schedules." Allowing all parties to save face, the Tibetan leader was received by the President of the German Bundestag, the Minister of Economic Cooperation and other non-government politicians. ${ }^{26}$

A shift to lower-ranked officials is also observable in Latin American countries. The Dalai Lama embarked on several trips throughout the region between 1989 and 2006. With respect to Dalai Lama receptions, a clear downward trend can be observed in terms of the rank of dignitaries met in the most important destination countries in the region, namely, Argentina, Brazil, Chile and Mexico. While the Tibetan leader had been received by the respective president of these countries up to the year 1999, he has had to contend himself with being received by dignitaries of less political importance ever since. The case of Chile in 2006 provides a particularly interesting example where the local media suspected Chilean president Michelle Bachelet of avoiding a meeting with the Dalai Lama so as not to jeopardize ongoing negotiations for the country's first trade agreement with China. ${ }^{27}$ By that time, China had also become Chile's second most important trading partner after the United States.

While receptions of the Dalai Lama by official state representatives such as government members may provoke trade reductions, the matter should be different in instances where the Dalai Lama met with leaders of the political opposition. In an interview conducted in 2008, the Dalai Lama himself remarked that most politicians meet with him before they become minister or president. After taking office, however, the very same politicians tend to avoid meeting with him so as not to endanger trade ties with China. The Dalai Lama concluded that "economic relations with China gain the upper hand." ${ }^{28}$ New Zealand provides a prime example of such behavior. Prime Minister John Key, who was still in opposition in 2007 and critical of the incumbent government's decision not to receive the Dalai Lama, also chose not to meet with the religious figure in 2009 after his party had come into power.

\footnotetext{
${ }^{26}$ It should be noted that, according to the usual protocol, the president of the German parliament is a higherranking officer than the chancellor. Notwithstanding, the chancellor has significantly more political power and greater public visibility. Following the 'chancellor principle', he or she is responsible for all government policies and issues the formal policy guidelines.

27 “DALAI LAMA: CAN I EVER TELL YOU HOW SORRY I AM?" The Santiago Times, May $16^{\text {th }} 2006$, available at: http://www.santiagotimes.cl/index.php?option=com content\&view=article\&id=9130:DALAI-LAMA:-CAN-I-EVERTELL-YOU-HOW-SORRY-I-AM?\&catid=1:other\&ltemid=38.

${ }^{28}$ „Ich will eine echte Autonomie," Cicero Magazin für Politische Kultur, 2009, own translation, available at: http://www.cicero.de/97.php?ress id=1\&item=2503.
} 
Therefore, the 'Dalai Lama Effect' should depend on the rank or the political importance of the dignitary met. Meetings with higher-ranked politicians pose a greater affront to the Chinese, who may then retaliate through a more pronounced reduction in bilateral trade:

Hypothesis 2: The detrimental effect of Dalai Lama meetings on trade grows with the rank of the dignitary met.

\section{Hypothesis 3: Evolvement over time}

Assuming that the reduction of commercial activity is intended to convey a warning to other trading partners, extensive prolongation of the measure might cause the implied welfare losses to outweigh the political benefits that China attains from increased political compliance of its trading partners. Facing a trade-off between the economic losses from trade diversion and the political gains from stabilizing the regime, it is in China's interest that trade ties are restored as quickly as possible to reduce the losses that arise from the political bias in its importing decisions. In particular, it seems reasonable to believe that China cannot afford to substitute more differentiated goods from a Dalai Lama-receiving country in the long run. At the same time, the partner economies are also interested in a restoration of trade ties with China and are likely to direct diplomatic efforts towards restoring these bilateral relations.

Anecdotal evidence confirms that diplomatic ties are usually restored after some period of time has passed following a reception of the Dalai Lama. However, China expects countries to make diplomatic concessions to correct for what it coins as their "wrongdoings". For example, nine months after the meeting between French President Nicolas Sarkozy and the Dalai Lama, bilateral relations were mended with considerable diplomatic efforts towards reconciliation. Shortly after a declaration of France that it recognized Tibet as integral part of the Chinese territory, France was due to receive a new Chinese trade delegation. In an article titled "France goes back on China's shopping list," the China Daily emphasizes a causal link between France's compliance and the re-establishment of bilateral relations. ${ }^{29}$

Similar reconciliation had to be achieved between China and Austria in September 2007. After a meeting between the Dalai Lama and Austrian Chancellor Alfred Gusenbauer, diplomatic relations between Austria and China deteriorated significantly, leading to what the media described as a "minor ice-age" between the two countries. Media reported that Austrian diplomats were banned from contact with Chinese officials for about one year. In

29 "France goes back on China's shopping list," China Daily, October $29^{\text {th }} 2009$, available at: http://www.chinadaily.com.cn/china/2009-10/29/content 8865307.htm. 
October 2008, a state visit of the Austrian chancellor in Beijing marked the end of the diplomatic tensions caused by the Dalai Lama reception. ${ }^{30}$

Therefore, we expect exports to China to recover after a while, i.e., that the tradedeteriorating effect of Dalai Lama meetings is only of temporary nature:

Hypothesis 3: The trade-deteriorating 'Dalai Lama Effect' disappears as bilateral relations between China and partner countries recover.

If purchases were only postponed as a signal of temporary Chinese discontent after a Dalai Lama meeting, there might even occur a positive 'Dalai Lama Effect' after a while as Chinese imports rebound from past cutbacks.

\section{Empirical Analysis}

\subsection{Data and Method}

We estimate econometrically whether and to what extent the diplomatic tensions caused by official receptions of the Dalai Lama impact negatively on the volume of exports to China. Our econometric model builds on the gravity equation of international trade, the workhorse of statistical analyses of trade flows, which translates Newton's 'Law of Universal Gravitation' to economics. The gravity model assumes that bilateral trade is proportional to the product of the trading partners' economic masses, proxied by GDP, and inversely proportional to the geographic distance between them. In order to control for country heterogeneity, we make use of partner country fixed effects. The effect of bilateral distance and other time-invariant factors, such as being landlocked or contiguous, is thus captured by the partner country fixed effects. In addition to partner country GDP, we add population size and the bilateral exchange rate to our specification, two frequently used variables in the gravity framework. Moreover, we control for time-specific factors by including dummy variables for each time period. We run the following econometric model:

$$
\text { exports }_{i t}=\beta_{1} \text { dalai }_{i t}+\beta_{2} g d p_{i t}+\beta_{3} \text { pop }_{i t}+\beta_{4} \text { exch }_{i t}+\gamma_{t}+\delta_{i}+\varepsilon_{i t}
$$

where exports it $_{\text {is }}$ the log of exports of partner country $i$ to China at time $t$ in current US dollars; $g d p_{i t}$ is the log of the partner country's gross domestic product in current US dollars; pop $_{i t}$ is the log of the partner country's population size; $\operatorname{exch}_{i t}$ is a nominal exchange rate index of the partner country's local currency unit in Yuan; $\gamma_{t}$ and $\delta_{i}$ are time and country fixed effects; and $\varepsilon_{i t}$ is a stochastic error. Trade data is obtained from the United Nations

\footnotetext{
30 "Gusenbauer: Irritationen mit China ausgeräumt,“ Die Presse.com, October $24^{\text {th }} 2008$, available at: http://diepresse.com/home/politik/aussenpolitik/425083/index.do?from=suche.intern.portal.
} 
COMTRADE database. ${ }^{31}$ Data on GDP, population size and exchange rates are drawn from the World Development Indicators (World Bank 2009).

Our variable of interest is the binary dummy variable dalai $_{i t}$, which takes a value of 1 if the Dalai Lama was received by a dignitary in the partner country in year $t$ or $t-1 .^{32}$ Information on the travel pattern of the Buddhist leader is obtained from the Office of His Holiness the 14th Dalai Lama. ${ }^{33}$ The variable is coded in four different ways: In its narrowest definition, we only include Dalai Lama meetings with heads of state or government. Our second definition extends the first by including all meetings between the Dalai Lama and government members. By also adding encounters with speakers of parliament, the third definition produces a dummy variable that accounts for all meetings between the Dalai Lama and national officials. Finally, we construct a variable that incorporates all meetings of the Tibetan leader that are listed by the Office of the Dalai Lama. This definition also includes regional leaders, party leaders, ex-presidents, ambassadors and scientists, among others. A detailed overview on the various definitions of the Dalai Lama dummy is provided in Table A1. Furthermore, we construct a binary dummy variable that takes a value of 1 if the Dalai Lama travelled to a Chinese trading partner country in a given year, irrespective of whether or not the Tibetan leader met with any dignitary there.

Our dataset covers the period 1991 to 2008, starting with the end of the Cold War and concluding with the most recent year for which trade data is currently available. Hypothesizing that a potential 'Dalai Lama Effect' might only be observable in more recent years, in which China's economic and political power grew significantly, we furthermore split our dataset into two periods: 1991-2001 and 2002-2008. Several arguments motivate 2002 as an appropriate point at which to split our sample. First, the leadership change that occurred when Huo Jintao took power of the Communist Party in 2002 may have reoriented China's foreign policy towards a more assertive advocacy of its global interests. Second, China became a WTO member in December 2001, which is likely to have significantly affected China's trading relations. Third, the September 11 attacks mark an important change in the global political order comparable to the end of the Cold War, which, in turn, marks the first year of our full sample. Next, we extend the analysis by restricting our sample to European partner countries to compare the results from previous estimations with those

\footnotetext{
${ }^{31}$ Since Belgium and Luxembourg did not report trade data separately for the years prior to 1999 , we use the GDP-weighted values of exports from Belgium-Luxembourg instead.

${ }^{32}$ The reason why we also include the lagged value is because it may take some time for the diplomatic tensions to translate into an actual decrease in trade values. Since trade flows are tied to contracts, the 'Dalai Lama Effect' may only become visible in trade statistics with a certain time delay. However, our results do not hinge on this assumption. At a later point, we also show results for different definitions of the variable of interest.

${ }^{33}$ Data is available at http://www.dalailama.com/. Information was completed with information provided on www.buddhismtoday.com.
} 
for this more homogenous set of countries. ${ }^{34}$ Europe has been the most important travel destination of the Tibetan head of government-in-exile. Leaving aside the Dalai Lama's host country India, of the 266 trips that the he made between 1991 and 2008, 160 of them were to European countries.

All models are estimated using two estimation strategies: First, we run Fixed Effects regressions. Standard errors are adjusted for clustering across partner countries since a modified Wald test indicates groupwise heteroskedasticity. ${ }^{35}$ Second, we rerun all models using Feasible Generalized Least Squares (FGLS) to account for cross-sectional heteroskedasticity across panels and autocorrelation. ${ }^{36}$ We employ a common AR(1) term as an estimation with a panel-specific $\mathrm{AR}(1)$ term would lead to biased results. As noted by Beck and Katz (1995), in contrast to a panel-specific $A R(1)$ term, the use of the FGLS correction for a common $\mathrm{AR}(1)$ is unlikely to lead to inaccurate estimations of the standard errors.

Figure 1 provides a geographical overview of the Dalai Lama's travel pattern between 1991 and 2008, whereas Figure 2 and Figure 3 show a map indicating where and how many times the Dalai Lama was received by a government official or a political leader, respectively. In many cases, the Dalai Lama was not received by any government member during a visit to a country. Russia and Spain, both of which struggle with independence movements, are examples of this. Table A2 lists all the variables employed in the analysis along with their definitions and sources. Table A3 provides descriptive statistics on all variables. Finally, Table A4 lists all countries included in the analysis.

\subsection{Main results}

Table 1.1 reports empirical results for the entire sample testing our first hypothesis that meetings between the Dalai Lama and foreign officials have a trade-deteriorating effect. Results are reported for both Fixed Effects and FGLS. Starting with the results from the Fixed Effects regression, we find a negative coefficient on our dummy variable that takes a value of 1 if a government member has received the Tibetan leader in the current or previous year. However, the coefficient is only statistically significant in the second sub-period, which

\footnotetext{
${ }^{34}$ Our definition of European countries excludes members of the Community of Independent States (CIS) to create a rather homogeneous group of countries. However, our results do not hinge on this definition.

${ }^{35}$ There is an emerging literature on biased estimates caused by the prevalence of zero trade flows in gravity models. In our sample, however, this issue seems to be negligible since the number of zero export flows is very small in our sample ( 57 of 2,269 observations).

${ }^{36}$ Following the results of the Wooldridge Test for Serial Autocorrelation, we reject the null hypothesis of 'no first order autocorrelation' in our sample.
} 
covers the Hu Jintao era (2002-2008). ${ }^{37}$ This result is in line with the increased political and economic power China acquired in the world in recent years. We find that Dalai Lama meetings decrease exports to China by $12.5 \%$ on average.$^{38}$ The coefficient is statistically significant at the five percent level. This effect is comparable in size to the effect of a state visit in Nitsch (2007) - though, of course, running in the opposite direction. FGLS results confirm the negative effect of Dalai Lama receptions on exports to China in the second subperiod. The expected impact on trade is significant at the five percent level and, with $5.7 \%$, considerably smaller than the effect estimated under Fixed Effects. In addition, the FGLS results unveil a negative effect for the first sub-period as well as for the overall sample. Closer investigation, however, reveals that this finding is driven by SITC product group 9, a rather heterogeneous group of products. ${ }^{39}$

In five of the six models in Table 1.1, the coefficient on GDP is positive and thus in line with the gravity model of trade. It is only in the Fixed Effects model for the second sub-period that we do not find the expected positive coefficient on GDP. However, if we exclude the time dummies, the coefficient becomes positive and significant (Results available upon request). A possible explanation for this might be that China's major trading partners were on the same business cycle during the second sub-period. Turning to the effect of the population size of China's trading partners, the corresponding coefficient is positive in all models, but not significant at conventional levels in the first sub-period. This positive coefficient suggests the existence of export-promoting scale effects as a result of a larger population size. The coefficient on the nominal exchange rate is positive in the FGLS estimations for the overall sample and the second sub-period, which shows that a depreciation of the partner country's currency with respect to the Chinese Renminbi has a positive effect on their exports to China. Summing up to this point, empirical results consistently confirm that there is a tradedeteriorating effect caused by foreign officials receiving the Dalai Lama in the 2002- 2008 period (Hu Jintao era). In what follows, we thus restrict our analysis to this relevant time period.

Column 2 of Table 1.2 shows results for a sample restricted to the more homogenous group of European countries that accounts for roughly half of all Dalai Lama receptions by government members. For the reader's convenience, we also show the results of our

\footnotetext{
${ }^{37}$ As a robustness check, we ran 159 regressions of the same model specification, each time excluding one of China's trading partners. In each case, the coefficient remained negative and statistically significant at conventional levels.

${ }^{38} \exp (-0.133)-1=-12.5 \%$

${ }^{39}$ We ran the same regression with product subgroups and found results in the first period (1991-2001) to be driven by exports from SITC group 9 ('Commodities and transactions not classified elsewhere in the SITC'). The negative significant effect of Dalai Lama meetings on exports vanishes when we exclude this group from the regression (Results available on request). SITC product group 9 consists of 'Postal packages not classified according to kind', 'Special transactions and commodities not classified according to kind', 'Coin (other than gold coin), not being legal tender', and 'Gold, non-monetary (excluding gold ores and concentrates)'.
} 
baseline regressions from Table 1.1 in column 1 (Fixed Effects) and column 6 (FGLS) of Table 1.2. We find evidence in favor of a trade-deteriorating effect also in our European subsample. The estimated negative effect of Dalai Lama meetings at government level on European exports to China amounts to $11.5 \%$ in the Fixed Effects regression and $13.1 \%$ in the FGLS regression.

Next, we include three additional control variables to our baseline regression to further test the robustness of our results. In a first step, we assess the effect of partner countries' export orientation on exports to China. While time-invariant country characteristics are captured by the country fixed effects, changes in export orientation across time are not accounted for in our baseline model. We hypothesize that exports to China grow over time when a partner country's export orientation increases. The export orientation of China's trading partners is measured as the total exports to all countries except China as a share of GDP. Trade data is again retrieved from UN COMTRADE and GDP data is obtained from the World Development Indicators (World Bank 2009). The effect of export orientation is found to be insignificant in the Fixed Effects regression (column 3). However, in the FGLS estimation, the coefficient is significant at the one percent level and correctly signed (column 8). Independently of the estimation strategy, the coefficient on our Dalai Lama variable is stable and remains significant at conventional levels.

As a second control variable, we add the log of the trade-weighted bilateral tariff rate to our baseline model in order to account for tariff barriers to trade between each country and China. ${ }^{40}$ Tariff data is taken from the UNCTAD-TRAINS database. In both regression frameworks, the coefficient on the dummy variable for the reception of the Dalai Lama by a government member is robust to the inclusion of tariff rates. While the tariff coefficient is found to be negative, as in line with theory, it is only significant in the FGLS estimation. The addition of tariff rates slightly increases the absolute size of the coefficient on the Dalai Lama variable in the FGLS framework (column 9) and leaves the coefficient in the Fixed Effects setting virtually unchanged (column 4). In both cases, the coefficient remains significant at the five percent level. This finding can be taken as an indication that the trade-reducing 'Dalai Lama Effect' does not operate via an increase of tariff barriers.

The third additional control variable aims to account for the effect of political friendship or hostility on trade with China. A frequently used measure for the extent of bilateral friendship is the degree to which countries vote in line with each other in the United Nations General Assembly (UNGA) (e.g., Richardson and Kegley 1980, Barro and Lee 2005, Dreher and

\footnotetext{
${ }^{40}$ Arguably, China's import tariffs themselves may be affected by diplomatic tensions caused by meetings of foreign officials with the Tibetan leader. Hence, the estimated coefficient on the Dalai Lama variable has to be attributed to other channels than the bilateral tariff rate.
} 
Jensen 2007, Kastner 2007, Dreher and Gassebner 2008). The measure, though it has its drawbacks, also has the advantage that it is available for virtually every country in the world over a long time period. We construct a variable for capturing the voting coincidence at the assembly using the same method as Richardson and Kegley (1980) and Thacker (1999). ${ }^{41}$ Therefore, our indicator of friendship with China is the number of times that a trading partner had the same voting behavior as China as a fraction of all voting instances. Votes in agreement are coded as 1 , votes in disagreement as 0 and abstentions and absences as 0.5. The regressions in columns 5 and 10 in Table 1.2 show that greater amity with China seems to promote trade, but that the effect is only statistically significant in the FGLS regression and has a negligible impact on the size of the Dalai Lama dummy variable.

In order to test Hypothesis 2, we run a modified version of the basic regression for the relevant time period (2002-2008), accounting for the different ranks of dignitaries met by the Dalai Lama. To this end, we include four dummy variables with increasingly broader definitions of dignitaries met. Furthermore, we include a dummy variable, which takes a value of 1 if the Dalai Lama travelled to the country - regardless of whether he was received by any dignitary. All dummy variables take a value of 1 if an event was registered in the current or previous year.

The regressions in columns 1 to 5 (Fixed Effects) and 10 to 14 (FGLS) in Table 2 confirm our hypothesis that the trade deteriorations caused by Dalai Lama meetings are associated with the rank of the dignitary that receives the Tibetan leader. We find that meetings between the Dalai Lama and political leaders, defined as head of state or government, have the greatest significant negative impact on exports to China. Dalai Lama meetings at highest political level reduce exports to China by $16.9 \%$ according to the Fixed Effects results and by $8.1 \%$ in our FGLS regression framework. Smaller, but still significant, effects are found when the definition of our variable of interest is extended to include government members and national officials, respectively. The effect is again smaller for the group including all dignitaries listed by the Office of the Dalai Lama. The corresponding coefficient is only significant at the $10 \%$ level in the FGLS regression and even becomes statistically insignificant at conventional levels in the Fixed Effects regression.

Since meetings with political leaders seem to have the highest impact, we test whether additional effects occur when the Dalai Lama is furthermore received by lower ranked dignitaries. As shown in columns 6 to 8 (Fixed Effects) and columns 15 to 17 (FGLS), there is no additional effect for lower-ranked dignitaries meeting the Dalai Lama in addition to the effect found for political leaders. When controlling for receptions at the highest political level,

\footnotetext{
${ }^{41}$ The UNGA roll-call voting data is made available by Voeten and Merdzanovic (2009). We thank Axel Dreher for providing us with a Stata do-file to process the data.
} 
each coefficient for meetings at a lower level is not statistically significant at conventional levels. ${ }^{42}$ The coefficient on the dummy indicating the presence of the Dalai Lama in the country - irrespective of whether he was received by a dignitary - is statistically not significant at conventional levels in the Fixed Effects (column 5) and loses its significance in the FGLS regression when controlling whether an encounter with the Tibetan leader took place (column 18). This underlines that the effect is only caused by a meeting with a foreign leader whereas the mere presence of the Dalai Lama in the respective country has no effect.

Having shown that the trade-deteriorating effect is driven by meetings with heads of state or government, we focus on these meetings in the following regression analyses. Table 3 shows how the 'Dalai Lama Effect' evolves over time in a Fixed Effects and in an FGLS regression framework (Hypothesis 3). In order to compare the effect of Dalai Lama meetings over time, we include separate dummy variables that take a value of 1 if the Tibetan leader is received by a political leader in the next year, current year, previous year, two years ago and three years ago, respectively. Starting again with the worldwide sample, we find statistically significant negative coefficients on the Dalai Lama dummies for the current and previous years. Both coefficients are similar in size and a t-test does not reject the null hypothesis that the two coefficients are equal in size at the $10 \%$ level. All other coefficients on the Dalai Lama variables are not statistically significant at conventional levels. We thus conclude that the trade-reducing impact of Dalai Lama meetings disappears after two years, which confirms Hypothesis 3. Turning to our smaller European sample, we find a similar pattern. The coefficient for Dalai Lama meetings in the current year is statistically significant at the five percent level, but the coefficient on the dummy for a Dalai Lama reception in the previous year loses significance in the Fixed Effects regression, while retaining significance in the FGLS regression.

\subsection{Endogeneity concerns}

In analogy to the reverse causal relationship between trade and military conflicts (e.g., Glick and Taylor 2005), the precise nature of the causal link between diplomatic conflicts and trade is unclear. On the one hand, we hypothesize that receiving the Dalai Lama leads to reduced exports to China. On the other hand, stronger commercial ties might also make it less likely that a political leader invites the Tibetan head of government-in-exile in the first place. There are good reasons to believe that a country is more reluctant to receive the Buddhist leader if

\footnotetext{
${ }^{42}$ When restricting our sample to European countries, a similar pattern emerges. Once more, we find the largest effect for Dalai Lama meetings with political leaders. Again, the coefficients for Dalai Lama meetings with lowerranked dignitaries are substantially smaller. In the Fixed Effects regression, however, the size of the coefficient for a Dalai Lama meeting with any dignitary outperforms the size of the corresponding dummy restricted to government members or national officials. Results are available upon request.
} 
it has a well-established trade relationship with China, which it does not want to jeopardize. In addition to this reverse causality problem, third variables might be omitted that impact on both Dalai Lama meetings and exports to China.

We employ a Two-Stage-Least-Squares (2SLS) model to account for the potential endogeneity of Dalai Lama meetings. The crucial point in a 2SLS regression framework is the choice of an appropriate instrument, which explains sufficiently well Dalai Lama meetings with political leaders, but is uncorrelated with the error term in the second stage regression. According to the exclusion restriction, an appropriate instrument should not affect exports to China through channels other than the potentially endogenous variable, i.e., the dummy for Dalai Lama receptions. In other words, an appropriate instrument should have no direct influence on exports to China. In order to find suitable instruments, one needs to get a better understanding of the Dalai Lama's travel behavior. According to the Dalai Lama himself, most visits abroad follow from invitations from Tibetan and Buddhist communities (Gyatso 1990). During his stays abroad, the Dalai Lama gives lectures and religious speeches and meets local Buddhist communities. While most meetings with lower-ranked dignitaries are scheduled long in advance, it is usually unclear some weeks or even days before the Dalai Lama embarks on a journey, whether he will be received by high-ranked officials. ${ }^{43}$ In some cases, the head of state or government just "drops in" while the Dalai Lama is being received by a lower-ranked government member. The political leader's decision process of whether to receive the Dalai Lama or not is usually accompanied by discussions in the media and demands from pro-Tibet lobby groups.

We employ the following three instruments in an attempt to control for endogeneity: The first instrument is the binary dummy variable discussed above, which takes a value of 1 if the Dalai Lama travelled to a partner country in a given year. The underlying idea is that the Tibetan leader is more likely to meet with officials in those years in which he travels to their respective partner countries. Most meetings with foreign dignitaries take place in the dignitary's own country, although Dalai Lama meetings have also occurred in third-party countries such as in 2008 when French president Nicolas Sarkozy met with the Dalai Lama in Poland. As outlined above, the Dalai Lama usually fixes his travel itinerary based on invitations from Buddhist or Tibetan communities to give teachings and public talks. Since his travel plans do generally not follow invitations from political leaders, we assume that our instrument is exogenous. The validity of the instrument is further supported by the empirical

\footnotetext{
${ }^{43}$ For example, shortly before the Dalai Lama's arrival in Italy in 2003 , Prime Minister Silvio Berlusconi left open whether he would accept the invitation of the Italian Parliamentary Group for Tibet to meet with the Tibetan leader. Finally, he refused the invitation. In the forerun of a trip to Mongolia in 2006, it remained unclear whether or not the Dalai Lama would be received by President Nambaryn Enkhbayar during his stay in the country. In the end, no meeting was scheduled. In a similar manner, the encounter of the Austrian chancellor Alfred Gusenbauer in 2007 was made public only one day before the actual meeting took place.
} 
results in Table 2, which shows that Dalai Lama travels do not have a statistically significant direct effect on exports to China. Our second instrument is the number of days that the Dalai Lama spent in a partner country. We hypothesize that the longer the duration of the Dalai Lama's stay in a country, the greater will be the public awareness of his presence in the country, the more intense will be the public discussion regarding his potential official reception, and the greater will be the pressure on political leaders to receive him.

As a third instrument, we use the number of Tibet Support Groups (TSG) in a trading partner country. TSGs are non-governmental organizations formed voluntarily and maintained by private individuals with the aim of rallying regional, national, or international awareness of and support for the Tibet issue. TSGs work independently from the Central Tibetan Administration and act as non-profit organizations that are open to any individuals willing to join the pro-Tibet movement. The larger the pro-Tibetan network in a partner country, the more inclined the political leader might be to receive the Dalai Lama in order to satisfy the demands of these pressure groups. Moreover, the number of TSGs may serve as a proxy for the extent to which a country's population is interested in the Tibet issue.

The dataset on the number of TSGs was established based on a list of pro-Tibet movements that was released by the Central Tibetan Administration in exile. ${ }^{44}$ We construct a time series by collecting information on the year of foundation of each TSG to account for the evolution of the pro-Tibet movement over time. In order to get information for those TSGs that do not provide this information on their homepage, we conducted a survey via e-mail and fax. Using this approach, we obtained information on the founding year for about $53.8 \%$ of all listed 295 organizations. Unfortunately, insufficient information is available on the number of members of each group so that we cannot account for differences in size between Tibet NGOs. With 31 recorded organizations, most TSGs in our sample are located in France, followed by the United States with 20 Tibet NGOs.

The first stage results of our 2SLS estimation approach (not displayed) are in line with our expectations: the likelihood that a political leader meets the Dalai Lama increases when the Tibetan head of government in exile travels to the leader's country, increases with the duration of the visit and also increases with the number of Tibet Support Groups in the partner country. The Angrist-Pischke test of excluded instruments displayed in Table 6 generally underlines the relevance of the instruments selected in the first stage. Only in the smaller European sample does the F statistic fall below the critical rule of thumb value of 10 (Staiger and Stock 1997).

${ }^{44}$ www.tibet.net 
The regressions in columns 1 to 5 of Table 4 show the results for the second stage regressions of our 2SLS approach. ${ }^{45}$ Again, we present results for the relevant time period (2002-2008). Starting with the worldwide sample (column 1), the coefficient on the dummy variable indicating whether the Dalai Lama was received by a head of state or head of government in the current or previous year is negative and statistically significant, i.e., we still find that Dalai Lama meetings have a trade-deteriorating effect when controlling for potential endogeneity. The coefficient is somewhat larger than in the Fixed Effects regression (Table 1.2, column 1). For the European subsample, displayed in column 2 of Table 4, the Dalai Lama coefficient is significant at the five percent level and again is larger than in the Fixed Effects regression (Table 1.2, column 2).

In order to shed light on the timing of the 'Dalai Lama Effect', we include two dummy variables, the first taking a value of 1 if a Dalai Lama meeting took place in the current period and the second taking a value of 1 if the Dalai Lama was received in the previous period. The results in column 3 of Table 4 show that the coefficients for both dummy variables have the expected negative signs, are of similar size and are significant at the ten percent level. Tests for overidentification (Hansen $\mathrm{J}$ ) and tests for underidentification (Kleinbergen Paap LM test) also confirm the validity of our instruments. Even though the 2SLS regression results support our previous findings, note that the $C$ test for endogeneity does not reject the null hypothesis of exogeneity of the Dalai Lama dummy. ${ }^{46}$ Consequently, the Fixed Effects estimates discussed in Section 4.2 are more efficient than the 2SLS estimates.

Next, we tackle a further endogeneity issue, which stems from the potential endogeneity of lagged export values in an extended model. Since trade relationships are persistent over time, we include lagged exports as an additional explanatory variable in order to explain current exports to China as a function of past export values. Established commercial ties and signed contracts mean that exports evolve with inertia. It is possible that the lagged exports variable is endogenous in a short panel, which could lead to biased results (Nickell 1981). Unobserved panel level effects may be correlated with lagged exports, thereby making the 2SLS estimator inconsistent. In order to address this issue, we apply the two-step System GMM estimator, which incorporates equations in first differences and in levels (Arellano and Bover 1995, Blundell and Bond 1998). Since we have a small $T$ in our setting $(T=7)$, we employ the Windmeijer correction to obtain corrected standard errors, which are larger and much more reliable in finite samples (Windmeijer 2005). Meetings with the Dalai Lama are treated as endogenous and all additional covariates as strictly exogenous. Furthermore, we

\footnotetext{
${ }^{45}$ All results are based on the user-written Stata command xtivreg2 (Schaffer 2005).

${ }^{46}$ Under conditional homoskedasticity, the C statistic is numerically equal to the Durbin-Wu-Hausman test. However, its main advantage is that it is robust to violations of conditional homoskedasticity (see Hayashi 2000 , pp. 232-234).
} 
include time fixed effects and employ the same external instruments as in the 2SLS regression framework discussed above. To limit the number of instruments, the matrix of instruments is collapsed as proposed in Roodman (2009).

Before proceeding to the GMM estimation results, column 4 of Table 4 reports for comparison the 2SLS results when lagged exports are included as an additional control variable. The coefficient on lagged exports to China is statistically significant at the five percent level. Interestingly, the Dalai Lama dummy indicating a meeting with a political leader in the previous period becomes insignificant once we include the lagged exports variable. Arguably, the 'Dalai Lama Effect' of meetings in the previous period is already (partially) captured in the lagged export variable. However, the dummy variable indicating a reception of the Tibetan leader in the current period remains statistically significant at conventional levels as expected. In column 5 , we therefore exclude the dummy variable indicating a Dalai Lama meeting in the previous period. The coefficients on the remaining variables remain virtually unchanged.

Column 6 shows our GMM regression results for the worldwide sample. ${ }^{47}$ The estimated coefficient on Dalai Lama meetings is negative, statistically significant at the five percent level, and of similar size as the corresponding value in the 2SLS setting. The coefficient on the lagged exports variable has the expected positive sign and is statistically significant at the five percent level. The Hansen test on the validity of the instruments used does not reject the exogeneity of the covariates. The Arellano-Bond test rejects the hypothesis of second order autocorrelation in the data, which needs to be absent in order for the estimator to be consistent. As a final robustness check, we exclude France in column 7 and India in column 8 from our sample, since both countries show extreme values in the distribution of our instrumental variables. France is by far the country with the most Tibet Support Groups (31 in our sample). India, in turn, is the country that experiences the longest Dalai Lama visits (up to 124 days per year). Nevertheless, when separately excluding the two countries from the GMM regression, our variable of interest remains statistically significant at the five percent level (columns 7 and 8 ). We therefore conclude that our results are not driven by these outliers.

\footnotetext{
${ }^{47}$ All results are based on the user-written Stata command xtabond2 (Roodman 2009).
} 


\subsection{Results by product group}

Finally, we investigate, which product groups drive the trade-deteriorating 'Dalai Lama Effect'. As indicated in the first column of Table 5.1, the value of exports to China is especially concentrated among the following SITC product groups: 'Machinery and transport equipment' $(41.0 \%$ of total exports to China), 'Manufactured goods classified chiefly by material' (13.3\%), 'Chemicals and related products' (12.4\%) and 'Crude materials, inedible, except fuels' (12.1\%). Exports of goods of the most important product group, 'Machinery and transport equipment', are expected to be closely associated with the state of political relations between countries as negotiations over the purchase of such goods are commonly carried out during the course of high-rank trade talks between national representatives and trade delegations. Running separate regressions for each SITC product group, Table 5.1 reports the full-sample results for the period 2002 to 2008. With the exception of 'Beverages and tobacco', the coefficients for all subgroups exhibit the expected negative sign in the Fixed Effects and FGLS regressions. However, only SITC group 7, which incorporates 'Machinery and transport equipment', the most important product group, turns out to be statistically significant in both regression frameworks. In the FGLS setting, we furthermore find a statistically significant and negative coefficient for 'Food, live animals', 'Crude materials' and 'Mineral fuels'.

Table 5.2 reports our results when the regressions are repeated for European countries. Results are found to be more diverse in the European sample. In the Fixed Effects regressions, we find negative and statistically significant results for the group of 'Food, live animals' and, once again, 'Machinery and transport equipment'. The coefficients on Dalai Lama meetings for the remaining groups are not statistically significant at conventional levels. In the FGLS regressions, statistically significant effects at conventional levels are found for 'Crude materials', 'Mineral fuels', 'Chemicals', and 'Machinery and transport equipment'.

Therefore, the only product group for which we find a statistically significant negative effect at conventional levels for both samples and both estimation techniques is 'Machinery and transport equipment'. This result suggests that the 'Dalai Lama Effect' exists predominantly for those goods that are commonly sold in the course of state visits and trade missions. Our results lend at least weak support in favor of a 'Dalai Lama Effect' operating through consumer opinions since negative coefficients on Dalai Lama meetings are found for consumption goods, namely 'Food, live animals' and 'Miscellaneous manufactured articles'. Finally, there is at least some evidence that strategic goods such as 'Crude materials' and 'Mineral fuels' are not free from political influences. This contradicts Polachek (1980), who argues that oil exports show a low export elasticity to conflict between trading partners, as 
oil-dependent economies have little choice but to continue importing the product regardless of any bilateral conflicts with an oil-exporting country.

\section{Conclusion}

The article contributes to the literature on the link between bilateral political relations and international trade through an assessment of the importance of the state of bilateral relations for trade with China. The Chinese administration frequently threatens, in a more-or-less open manner, that meetings between its trading partners' officials and the Dalai Lama will be met with animosity and lead to subsequent deterioration in their trade relationships. Using data on the travel pattern of the Dalai Lama, we run a gravity model of exports to China from 159 partner countries in 1991-2008 to test for political influences on China's trading decisions. All models are estimated using Fixed Effects with clustered standard errors and Feasible Generalized Least Squares (FGLS) with a common AR(1) term. In order to account for the potential endogeneity of meetings with the Dalai Lama, the number of Tibet Support Groups and the travel pattern of the Buddhist leader are used as instruments in 2SLS and GMM regressions.

Empirical evidence confirms the existence of a trade-deteriorating effect of Dalai Lama receptions for the Hu Jintao era (2002-2008). However, we find at best weak evidence to support the existence of such an effect in earlier years. While our results suggest that systematic trade reductions are only caused by meetings with heads of state or government, no additional impact is found for meetings between the Dalai Lama and lower-ranking officials. As a consequence of a political leader's reception of the Dalai Lama in the current or previous period, exports to China are found to decrease by $8.1 \%$ or $16.9 \%$, depending on the estimation technique used. Furthermore, we find that this effect will have disappeared two years after a meeting took place. Analyzing disaggregated export data, 'Machinery and transport equipment' is found to be the only product group with a consistent negative effect of Dalai Lama meetings on exports across samples and estimation techniques.

To sum up, we find strong evidence that bilateral political relations matter for trade with China, which lends support to the findings of the growing literature on the political determinants of trade. Chinese trade relations are not free of political biases and the country seems to exploit trade ties as a foreign policy tool. While political leaders should be aware of potential export losses when receiving the Dalai Lama, not meeting with him is not the only inevitable policy conclusion in order to safeguard commercial interests. Internationally coordinated receptions of the Dalai Lama by political leaders or even joint meetings are a possibility to reconcile economic interests with the demands to receive the Tibetan leader. 
Such a strategy may reduce China's scope to play one trading partner off against another. Nonetheless, with the increasing economic power of China and other emerging countries, the (ab)use of trade ties as a foreign policy tool is likely to gain in importance. 


\section{$\underline{\text { References }}$}

Aidt, T. S. and Gassebner, M. (2010). "Do Autocratic States Trade Less?" World Bank Economic Review 24(1), pp. 38-76.

Arellano, M. and Bover, O. (1995). "Another Look at the Instrumental Variable Estimation of Error-Components Models," Journal of Econometrics 68(1), pp. 29-51.

Baldwin, D. (1985). Economic Statecraft. Princeton, NJ: Princeton University Press.

Barro, R. J. and Lee, J.-W. (2005). "IMF Programs: Who Is Chosen and What Are the Effects?" Journal of Monetary Economics 52(7), pp. 1245-1269.

Beck, N. and Katz, J. N. (1995). "What To Do (and Not To Do) with Time-Series CrossSection Data", American Political Science Review 89(3), pp. 634-647.

Blundell, R. and Bond, S. (1998). "Initial Conditions and Moment Restrictions in Dynamic Panel Data Models," Journal of Econometrics 87(1), pp. 115-143.

Disdier, A.-C. and Mayer, T. (2007). "Je t'aime, moi non plus: Bilateral Opinions and International Trade," European Journal of Political Economy 23(4), pp. 1140-1159.

Dreher, A. and Gassebner, M. (2008). "Does Political Proximity to the U.S. Cause Terror?" Economics Letters 99(1), pp. 27-29.

Dreher, A. and Jensen, N. M. (2007). "Independent Actor or Agent? An Empirical Analysis of US Interests on IMF Conditions," Journal of Law \& Economics 50(1), pp. 105-124.

Gassebner, M., Keck, A. and Teh, R. (2010). "Shaken, Not Stirred: The Impact of Disasters on International Trade", Review of International Economics 18(2), pp. 351-368.

Gil-Pareja, S., Llorca, R. and Martínez Serrano, J. A. (2008). "Measuring the Impact of Regional Export Promotion: The Spanish Case," Papers in Regional Science 87(1), pp. 139-146.

Glick, R. and Taylor, A. (2005). "Collateral Damage: Trade Disruption and the Economic Impact of War", NBER Working Paper 11565.

Goldstein, M. C. (1997). The Snow Lion and the Dragon: China, Tibet, and the Dalai Lama. Berkeley, CA: University of California Press.

Goldstein, M. C. (1998). “The Dalai Lama's Dilemma,” Foreign Affairs 77(1), pp. 83-97. 
Gowa, J. and Mansfield, E. (1993). "Power Politics and International Trade", American Political Science Review, 87(2), pp. 408-420.

Gowa, J. and Mansfield, E. (2004). "Alliances, Imperfect Markets, and Major-Power Trade", International Organization 58(4), pp. 775-805.

Guiso, L., Sapienza, P. and Zingales, L. (2009). "Cultural Biases in Economic Exchange?" Quarterly Journal of Economics 124(3), pp. 1095-1131.

Gyatso, T. (1990). Freedom in Exile: The Autobiography of the Dalai Lama. New York, NY: Harper Perennial.

Hayashi, F. (2000). Econometrics. Princeton, NJ: Princeton University Press.

Hirschman, A. O. (1945). National Power and the Structure of Foreign Trade. Berkeley, CA: University of California Press.

Kastner, S. L. (2007). "When Do Conflicting Political Relations Affect International Trade?" Journal of Conflict Resolution 51(4), pp. 664-688.

Keohane, R. O., and Nye, J. S. (1977). Power and Interdependence: World Politics in Transition. Boston, MA: Little, Brown.

Keshk, O., Pollins, B. and Reuveny. R. (2004). "Trade Still Follows the Flag: The Primacy of Politics in a Simultaneous Model of Interdependence and Armed Conflict," Journal of Politics 66(4), pp. 1155-1179.

Mansfield, E., Milner, H. and Rosendorff, P. (2000). "Free to Trade: Democracies, Autocracies, and International Trade", American Political Science Review 94(2), pp. 305-322.

Martin, P., Mayer, T. and Thoenig, M. (2008). "Make Trade Not War?" Review of Economic Studies 75(3), pp. 865-900.

Méon, P.-G. and Sekkat, K. (2008). "Institutional Quality and Trade: Which Institutions? Which Trade?" Economic Inquiry 46(2), pp. 227-240.

Morrow, J. D., Siverson, R. M. and Tabares, T. (1998). "The Political Determinants of International Trade: The Major Powers, 1907-1990", American Political Science Review 92(4), pp. 649-661.

Nickell, S. J. (1981). "Biases in Dynamic Models with Fixed Effects," Econometrica 49(6), pp. 1417-1426. 
Nitsch, V. \& Schumacher, D. (2004). "Terrorism and International Trade: An Empirical Investigation," European Journal of Political Economy 20(2), pp. 423-433.

Nitsch, V. (2007). "State Visits and International Trade", World Economy 30(12), pp. 17971816.

Oneal, J. R., Russett, B. and Berbaum, M. L. (2003). "Causes of Peace: Democracy, Interdependence, and International Organizations, 1885-1992", International Studies Quarterly 47(3), pp. 371-393.

Polachek, S. W. (1980). "Conflict and Trade", Journal of Conflict Resolution 24(1), pp. 55-78.

Pollins, B. M. (1989). "Does Trade Still Follow the Flag?" American Political Science Review 83(2), pp. 465-480.

Richardson, N. and Kegley, C. (1980). "Trade Dependence and Foreign Policy Compliance", International Studies Quarterly 24(2), pp. 191-222.

Roodman, D. (2009). "How to Do xtabond2: An Introduction to "Difference" and "System" GMM in Stata", Stata Journal 9(1), pp. 86-136.

Rose, A. (2007). "The Foreign Service and Foreign Trade: Embassies as Export Promotion", World Economy 30(1), pp. 22-38.

Schaffer, M. E. (2005). "XTIVREG2: Stata Module to Perform Extended IV/2SLS, GMM and AC/HAC, LIML and k-Class Regression for Panel Data Models," Statistical Software Components S456501, Boston College Department of Economics, revised 28 Jun 2010.

Staiger, D. and Stock, J. H. (1997). "Instrumental Variables Regression with Weak Instruments," Econometrica 65(3), pp. 557-586.

Thacker, S. C. (1999). "The High Politics of IMF Lending”, World Politics 52, pp. 38-75.

Voeten, E. and Merdzanovic, A. (2009). "United Nations General Assembly Voting Data," available at: http://hdl.handle.net/1902.1/12379.

Windmeijer, F. (2005). "A Finite Sample Correction for the Variance of Linear Efficient Twostep GMM Estimators," Journal of Econometrics 126(1), pp. 25-51.

World Bank (2009). World Development Indicators, CD-Rom, Washington, DC. 
Table 1.1 Hypothesis 1: Exports to China and Dalai Lama meetings of government members (all countries)

\begin{tabular}{l|rrr|rrr} 
& \multicolumn{3}{|c|}{ Fixed Effects } & \multicolumn{3}{c}{ FGLS AR(1) } \\
& $1991-2008$ & $1991-2001$ & $2002-2008$ & $1991-2008$ & $1991-2001$ & $2002-2008$ \\
\hline DL meets government member & -0.104 & -0.101 & $-0.133^{* *}$ & $-0.079^{* *}$ & $-0.060^{*}$ & $-0.059^{* *}$ \\
& {$[0.288]$} & {$[0.355]$} & {$[0.027]$} & {$[0.021]$} & {$[0.067]$} & {$[0.011]$} \\
Log of GDP & $0.598^{* *}$ & $0.819^{* *}$ & -0.007 & $0.199^{* *}$ & $0.312^{* * *}$ & $0.382^{* * *}$ \\
& {$[0.019]$} & {$[0.040]$} & {$[0.981]$} & {$[0.010]$} & {$[0.004]$} & {$[0.000]$} \\
Log of population & $3.643^{* * *}$ & 2.809 & $3.411^{* *}$ & $0.498^{* * *}$ & 0.270 & $2.689^{* * *}$ \\
& {$[0.002]$} & {$[0.104]$} & {$[0.035]$} & {$[0.001]$} & {$[0.179]$} & {$[0.000]$} \\
Log of exchange rate & -0.047 & -0.058 & 0.158 & $0.042^{*}$ & -0.024 & $0.270^{* * *}$ \\
& {$[0.617]$} & {$[0.598]$} & {$[0.357]$} & {$[0.084]$} & {$[0.407]$} & {$[0.000]$} \\
\hline R squared & & & & & & \\
Observations & 0.444 & 0.129 & 0.280 & & & \\
Number of countries & 2062 & 1142 & 912 & 2062 & 1142 & 912 \\
& 159 & 148 & 151 & 159 & 148 & 151 \\
\hline
\end{tabular}

Note: All regressions with country and time fixed effects.

Robust $\mathrm{p}$ values in brackets; ${ }^{*}$ significant at $10 \%$; ${ }^{* *}$ significant at $5 \%$; ${ }^{* * *}$ significant at $1 \%$

Standard errors in OLS Fixed Effects regressions are adjusted for clustering across partner countries.

FGLS regressions are corrected for cross-sectional heteroskedasticity across panels and first order autocorrelation.

Table 1.2 Alternative model specifications: Exports to China and Dalai Lama meetings of government members (2002-2008)

\begin{tabular}{|c|c|c|c|c|c|c|c|c|c|c|}
\hline & \multicolumn{5}{|c|}{ Fixed Effects } & \multicolumn{5}{|c|}{ FGLS AR(1) } \\
\hline & $\begin{array}{l}\text { World } \\
\text { (1) }\end{array}$ & $\begin{array}{c}\text { Europe } \\
\text { (2) }\end{array}$ & $\begin{array}{c}\text { World } \\
\text { (3) }\end{array}$ & $\begin{array}{c}\text { World } \\
\text { (4) }\end{array}$ & $\begin{array}{c}\text { World } \\
(5)\end{array}$ & $\begin{array}{c}\text { World } \\
(6)\end{array}$ & $\begin{array}{c}\text { Europe } \\
(7)\end{array}$ & $\begin{array}{c}\text { World } \\
(8)\end{array}$ & $\begin{array}{l}\text { World } \\
(9)\end{array}$ & $\begin{array}{l}\text { World } \\
(10)\end{array}$ \\
\hline DL meets government member & $\begin{array}{r}-0.133^{* *} \\
{[0.027]}\end{array}$ & $\begin{array}{r}-0.122^{*} \\
{[0.098]}\end{array}$ & $\begin{array}{r}-0.136^{* *} \\
{[0.023]}\end{array}$ & $\begin{array}{r}-0.132^{* *} \\
{[0.030]}\end{array}$ & $\begin{array}{r}-0.127^{* *} \\
{[0.035]}\end{array}$ & $\begin{array}{r}-0.059^{* *} \\
{[0.011]}\end{array}$ & $\begin{array}{r}-0.140 * * * \\
{[0.003]}\end{array}$ & $\begin{array}{r}-0.043^{*} \\
{[0.084]}\end{array}$ & $\begin{array}{r}-0.065^{* *} \\
{[0.011]}\end{array}$ & $\begin{array}{r}-0.064 * * * \\
{[0.006]}\end{array}$ \\
\hline Log of GDP & $\begin{array}{r}-0.007 \\
{[0.981]}\end{array}$ & $\begin{array}{l}0.362 \\
{[0.587]}\end{array}$ & $\begin{array}{r}-0.025 \\
{[0.931]}\end{array}$ & $\begin{array}{r}-0.147 \\
{[0.640]}\end{array}$ & $\begin{array}{r}-0.014 \\
{[0.962]}\end{array}$ & $\begin{array}{r}0.382^{* * * *} \\
{[0.000]}\end{array}$ & $\begin{array}{r}0.691^{* * *} \\
{[0.000]}\end{array}$ & $\begin{array}{r}0.331^{* * * *} \\
{[0.000]}\end{array}$ & $\begin{array}{r}0.240^{* * * *} \\
{[0.002]}\end{array}$ & $\begin{array}{r}0.359 * * * \\
{[0.000]}\end{array}$ \\
\hline Log of population & $\begin{array}{r}3.411 * * \\
{[0.035]}\end{array}$ & $\begin{array}{l}2.208 \\
{[0.495]}\end{array}$ & $\begin{array}{r}3.250 * \\
{[0.055]}\end{array}$ & $\begin{array}{r}3.075^{*} \\
{[0.055]}\end{array}$ & $\begin{array}{r}3.325^{* *} \\
{[0.032]}\end{array}$ & $\begin{array}{r}2.689^{* * *} \\
{[0.000]}\end{array}$ & $\begin{array}{r}-0.123 \\
{[0.627]}\end{array}$ & $\begin{array}{r}3.487 * * * \\
{[0.000]}\end{array}$ & $\begin{array}{r}2.055^{* * *} \\
{[0.000]}\end{array}$ & $\begin{array}{r}2.638^{* * *} \\
{[0.000]}\end{array}$ \\
\hline Log of exchange rate & $\begin{array}{l}0.158 \\
{[0.357]}\end{array}$ & $\begin{array}{r}-1.086 \\
{[0.320]}\end{array}$ & $\begin{array}{r}0.029 \\
{[0.883]}\end{array}$ & $\begin{array}{r}0.101 \\
{[0.566]}\end{array}$ & $\begin{array}{l}0.129 \\
{[0.465]}\end{array}$ & $\begin{array}{r}0.270^{* * *} \\
{[0.000]}\end{array}$ & $\begin{array}{r}-0.445 \\
{[0.249]}\end{array}$ & $\begin{array}{r}0.140^{* *} \\
{[0.026]}\end{array}$ & $\begin{array}{r}0.186^{* *} \\
{[0.015]}\end{array}$ & $\begin{array}{r}0.268^{* * *} \\
{[0.000]}\end{array}$ \\
\hline Other exports / GDP & & & $\begin{array}{l}2.757 \\
{[0.150]}\end{array}$ & & & & & $\begin{array}{r}2.098^{* * * *} \\
{[0.000]}\end{array}$ & & \\
\hline Log of tariff rate & & & & $\begin{array}{r}-0.030 \\
{[0.761]}\end{array}$ & & & & & $\begin{array}{r}-0.064^{* * *} \\
{[0.000]}\end{array}$ & \\
\hline UNGA voting alignment & & & & & $\begin{array}{l}2.020 \\
{[0.208]}\end{array}$ & & & & & $\begin{array}{r}0.718^{* *} \\
{[0.030]}\end{array}$ \\
\hline R squared & 0.280 & 0.502 & 0.294 & 0.296 & 0.283 & & & & & \\
\hline Observations & 912 & 247 & 906 & 887 & 912 & 912 & 247 & 906 & 887 & 912 \\
\hline Number of countries & 151 & 36 & 150 & 148 & 151 & 151 & 36 & 150 & 148 & 151 \\
\hline
\end{tabular}

Robust p values in brackets; * significant at $10 \%$; ** significant at $5 \%$; *** significant at $1 \%$

Standard errors in OIS Fixed Effects regressions are adjusted for clustering across partner countries.

FGLS regressions are corrected for cross-sectional heteroskedasticity across panels and first order autocorrelation. 


\section{Table 2}

Hypothesis 2: Exports to China and Dalai Lama meetings at various political levels (all countries, 2002-2008)

\begin{tabular}{|c|c|}
\hline 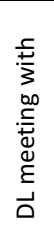 & $\begin{array}{l}\text { political leader } \\
\text { government member } \\
\text { national official } \\
\text { all dignitaries }\end{array}$ \\
\hline
\end{tabular}

DL visits country

\section{Log of GDP}

Log of population

Log of exchange rate

\begin{tabular}{|c|c|c|c|c|}
\hline Log of exchange rate & $\begin{array}{l}0.151 \\
{[0.380]}\end{array}$ & $\begin{array}{l}0.158 \\
{[0.357]}\end{array}$ & $\begin{array}{l}0.15 / \\
{[0.359]}\end{array}$ & $\begin{array}{l}0.158 \\
{[0.359}\end{array}$ \\
\hline R squared & 0.280 & 0.280 & 0.280 & 0.279 \\
\hline Observations & 912 & 912 & 912 & 912 \\
\hline Number of Countries & 151 & 151 & 151 & 151 \\
\hline
\end{tabular}

Fixed Effects

\begin{tabular}{|c|c|c|c|c|c|c|c|c|c|c|c|c|c|c|c|c|c|}
\hline \multicolumn{9}{|c|}{ Fixed Effects } & \multicolumn{9}{|c|}{ FGLS AR(1) } \\
\hline (1) & (2) & (3) & (4) & (5) & (6) & (7) & (8) & (9) & (10) & (11) & (12) & (13) & (14) & (15) & (16) & (17) & (18) \\
\hline $\begin{array}{r}-0.185^{* *} \\
{[0.011]}\end{array}$ & & & & & $\begin{array}{r}-0.193^{*} \\
{[0.068]}\end{array}$ & $\begin{array}{r}-0.177^{*} \\
{[0.083]}\end{array}$ & $\begin{array}{r}-0.208^{* *} \\
{[0.043]}\end{array}$ & $\begin{array}{r}-0.207^{* *} \\
{[0.017]}\end{array}$ & $\begin{array}{r}-0.084 * * * \\
{[0.002]}\end{array}$ & & & & & $\begin{array}{r}-0.082^{* *} \\
{[0.029]}\end{array}$ & $\begin{array}{r}-0.069^{* *} \\
{[0.040]}\end{array}$ & $\begin{array}{r}-0.076^{* *} \\
{[0.021]}\end{array}$ & $\begin{array}{r}-0.082^{* * * *} \\
{[0.006]}\end{array}$ \\
\hline & $-0.133 * *$ & & & & 0.010 & & & & & $-0.059 * *$ & & & & -0.003 & & & \\
\hline & {$[0.027]$} & $-0.128^{* *}$ & & & {$[0.90$} & -0.009 & & & & [0.011] & $-0.057 * *$ & & & [0.927] & -0.019 & & \\
\hline & & {$[0.029]$} & & & & {$[0.904]$} & & & & & [0.013] & & & & [0.476] & & \\
\hline & & & -0.086 & & & & 0.028 & & & & & $-0.047^{* *}$ & & & & -0.013 & \\
\hline & & & [0.169] & & & & {$[0.745]$} & & & & & {$[0.027]$} & & & & [0.599] & \\
\hline & & & & $\begin{array}{r}-0.058 \\
0.3111\end{array}$ & & & & $\begin{array}{r}0.033 \\
{[0.6171}\end{array}$ & & & & & $\begin{array}{r}-0.039 * \\
{[0.0621}\end{array}$ & & & & $\begin{array}{r}-0.013 \\
{[0.559]}\end{array}$ \\
\hline-0.031 & -0.007 & -0.006 & -0.005 & 0.009 & -0.032 & -0.030 & -0.032 & -0.036 & $0.351 * * *$ & $0.382^{* * *}$ & $0.386^{* * *}$ & $0.386^{* * *}$ & $0.402 * * *$ & $0.352^{* * *}$ & $0.357^{* * *}$ & $0.354^{* * *}$ & $0.355^{* * *}$ \\
\hline [0.920] & [0.981] & {$[0.984]$} & [0.988] & {$[0.976]$} & [0.919] & [0.922] & [0.918] & {$[0.908]$} & ]$\quad[0.000]$ & {$[0.000]$} & {$[0.000]$} & {$[0.000]$} & {$[0.000]$} & {$[0.000]$} & {$[0.000]$} & {$[0.000]$} & {$[0.000]$} \\
\hline $3.433^{* *}$ & $3.411 * *$ & $3.403^{* *}$ & $3.396 * *$ & $3.369 * *$ & $3.432 * *$ & $3.434^{* *}$ & $3.423 * *$ & $3.421 * *$ & $2.666^{* * *}$ & $2.689 * * *$ & $2.669 * * *$ & $2.679 * * *$ & $2.657^{* * *}$ & $2.667^{* * *}$ & $2.659 * * *$ & $2.688^{* * *}$ & $2.685^{* * *}$ \\
\hline [0.033] & [0.035] & [0.035] & {$[0.036]$} & {$[0.037]$} & [0.033] & [0.033] & [0.033] & {$[0.033]$} & ] [0.000] & {$[0.000]$} & {$[0.000]$} & {$[0.000]$} & {$[0.000]$} & {$[0.000]$} & {$[0.000]$} & {$[0.000]$} & {$[0.000]$} \\
\hline 0.151 & 0.158 & 0.157 & 0.158 & 0.165 & 0.150 & 0.151 & 0.151 & 0.149 & $0.268^{* * *}$ & $0.270^{* * *}$ & $0.269 * * *$ & $0.268 * * *$ & $0.281^{* * *}$ & $0.268^{* * *}$ & $0.265^{* * *}$ & $0.266^{* * *}$ & $0.269 * * *$ \\
\hline$[0.380]$ & {$[0.357]$} & [0.359] & {$[0.359]$} & {$[0.337]$} & {$[0.380]$} & {$[0.380]$} & [0.379] & {$[0.386]$} & ] [0.000] & {$[0.000]$} & {$[0.000]$} & {$[0.000]$} & {$[0.000]$} & {$[0.000]$} & {$[0.000]$} & {$[0.000]$} & {$[0.000]$} \\
\hline 0.280 & 0.280 & 0.280 & 0.279 & 0.279 & 0.280 & 0.280 & 0.280 & 0.280 & & & & & & & & & \\
\hline 912 & 912 & 912 & 91 & 912 & 912 & 912 & 912 & 912 & 912 & 912 & 912 & 912 & 912 & 912 & 912 & 912 & 912 \\
\hline 151 & 151 & 151 & 151 & 151 & 151 & 151 & 151 & 151 & 151 & 151 & 151 & 151 & 151 & 151 & 151 & 151 & 151 \\
\hline
\end{tabular}

Note: All regressions with country and timef

Standard errors in OLS Fixed Effects regressions are adjusted for clustering across partner countries. - FGLS regressions are corrected for cross-sectional heteroskedasticity across panels and first order autocorrelation 

leaders (time-event specification, 2002-2008)

\begin{tabular}{|c|c|c|c|c|}
\hline & \multicolumn{2}{|c|}{ Fixed Effects } & \multicolumn{2}{|c|}{ FGLS AR(1) } \\
\hline & World & Europe & World & Europe \\
\hline \multirow[t]{2}{*}{ DL met leader in $t+1$} & -0.113 & -0.092 & -0.044 & -0.037 \\
\hline & [0.203] & [0.276] & [0.155] & {$[0.629]$} \\
\hline \multirow[t]{2}{*}{$\mathrm{DL}$ met leader in $\mathrm{t}$} & $-0.189 * *$ & $-0.183 *$ & $-0.105 * * *$ & $-0.135^{*}$ \\
\hline & [0.011] & {$[0.065]$} & [0.001] & {$[0.064$} \\
\hline \multirow[t]{2}{*}{ DL met leader in $\mathrm{t}-1$} & $-0.192 * *$ & -0.150 & $-0.087 * *$ & $-0.318 * * *$ \\
\hline & [0.031] & {$[0.300]$} & [0.023] & {$[0.000]$} \\
\hline \multirow[t]{2}{*}{ DL met leader in $\mathrm{t}-2$} & 0.061 & 0.191 & 0.009 & 0.103 \\
\hline & [0.441] & {$[0.203]$} & [0.827] & {$[0.137]$} \\
\hline \multirow[t]{2}{*}{ DL met leader in $\mathrm{t}-3$} & -0.019 & 0.021 & -0.016 & -0.047 \\
\hline & [0.778] & {$[0.854]$} & [0.611] & [0.433] \\
\hline \multirow[t]{2}{*}{ Log of GDP } & -0.033 & 0.303 & $0.341 * * *$ & $0.559 * * *$ \\
\hline & [0.914] & {$[0.667]$} & {$[0.000]$} & {$[0.001]$} \\
\hline \multirow[t]{2}{*}{ Log of population } & $3.368 * *$ & 1.864 & $2.577 * * *$ & 0.074 \\
\hline & [0.042] & {$[0.547]$} & {$[0.000]$} & {$[0.782$} \\
\hline \multirow[t]{2}{*}{ Log of exchange rate } & 0.145 & -1.127 & $0.266 * * *$ & -0.435 \\
\hline & [0.399] & [0.304] & {$[0.000]$} & {$[0.259$} \\
\hline R squared & 0.281 & 0.507 & & \\
\hline Observations & 912 & 247 & 912 & 247 \\
\hline Number of Countries & 151 & 36 & 151 & 36 \\
\hline
\end{tabular}

Note: All regressions with country and time fixed effects.

Robust $\mathrm{p}$ values in brackets; ${ }^{*}$ significant at $10 \%$; ${ }^{* *}$ significant at $5 \%$; ${ }^{* * *}$ significant at $1 \%$

Standard errors in OLS Fixed Effects regressions are adjusted for clustering across partner countries.

FGLS regressions are corrected for cross-sectional heteroskedasticity across panels and first order autocorrelation. 
Table 4

Endogeneity: Exports to China and Dalai Lama meetings of political leaders (2002-2008)

\begin{tabular}{|c|c|c|c|c|c|c|c|c|}
\hline & \multicolumn{5}{|c|}{ 2SLS } & \multicolumn{3}{|c|}{ GMM } \\
\hline & $\begin{array}{c}\text { World } \\
\text { (1) }\end{array}$ & $\begin{array}{c}\text { Europe } \\
\text { (2) }\end{array}$ & $\begin{array}{c}\text { World } \\
\text { (3) }\end{array}$ & $\begin{array}{c}\text { World } \\
\text { (4) }\end{array}$ & $\begin{array}{c}\text { World } \\
\text { (5) }\end{array}$ & $\begin{array}{c}\text { World } \\
\text { (6) }\end{array}$ & $\begin{array}{c}\text { w/o FRA } \\
\text { (7) }\end{array}$ & $\begin{array}{c}\text { w/o IND } \\
\text { (8) }\end{array}$ \\
\hline DL meets political leader in t or $\mathrm{t}-1$ & $\begin{array}{r}-0.229 * \\
{[0.052]}\end{array}$ & $\begin{array}{r}-0.242^{* *} \\
{[0.014]}\end{array}$ & & & & & & \\
\hline DL meets political leader in $\mathrm{t}$ & & & $\begin{array}{r}-0.202^{*} \\
{[0.063]}\end{array}$ & $\begin{array}{r}-0.211^{*} \\
{[0.057]}\end{array}$ & $\begin{array}{r}-0.195^{*} \\
{[0.063]}\end{array}$ & $\begin{array}{r}-0.209 * * \\
{[0.019]}\end{array}$ & $\begin{array}{r}-0.245^{* *} \\
{[0.022]}\end{array}$ & $\begin{array}{r}-0.170 * * \\
{[0.027]}\end{array}$ \\
\hline DL meets political leader in $\mathrm{t}-1$ & & & $\begin{array}{r}-0.221^{*} \\
{[0.082]}\end{array}$ & $\begin{array}{r}-0.171 \\
{[0.134]}\end{array}$ & & & & \\
\hline Log of exports (t-1) & & & & $\begin{array}{r}0.197 * * \\
{[0.024]}\end{array}$ & $\begin{array}{r}0.198 * * \\
{[0.023]}\end{array}$ & $\begin{array}{r}0.364 * * * \\
{[0.010]}\end{array}$ & $\begin{array}{r}0.371^{* *} \\
{[0.013]}\end{array}$ & $\begin{array}{r}0.358^{* *} \\
{[0.012]}\end{array}$ \\
\hline Log of GDP & $\begin{array}{r}-0.041 \\
{[0.896]}\end{array}$ & $\begin{array}{r}0.255 \\
{[0.697]}\end{array}$ & $\begin{array}{r}-0.040 \\
{[0.897]}\end{array}$ & $\begin{array}{c}0.064 \\
{[0.822]}\end{array}$ & $\begin{array}{l}0.089 \\
{[0.750]}\end{array}$ & $\begin{array}{r}0.834 * * * \\
{[0.000]}\end{array}$ & $\begin{array}{r}0.822 * * * \\
{[0.000]}\end{array}$ & $\begin{array}{r}0.824 * * * \\
{[0.000]}\end{array}$ \\
\hline Log of population & $\begin{array}{r}3.458^{* *} \\
{[0.031]}\end{array}$ & $\begin{array}{r}2.360 \\
{[0.477]}\end{array}$ & $\begin{array}{r}3.447^{* *} \\
{[0.032]}\end{array}$ & $\begin{array}{r}3.505^{* * * *} \\
{[0.009]}\end{array}$ & $\begin{array}{r}3.401^{* *} \\
{[0.011]}\end{array}$ & $\begin{array}{r}0.108 * \\
{[0.076]}\end{array}$ & $\begin{array}{r}0.130 * \\
{[0.095]}\end{array}$ & $\begin{array}{r}0.137 \\
{[0.111]}\end{array}$ \\
\hline Log of exchange rate & $\begin{array}{c}0.147 \\
{[0.391]}\end{array}$ & $\begin{array}{r}-1.117 \\
{[0.305]}\end{array}$ & $\begin{array}{c}0.147 \\
{[0.391]}\end{array}$ & $\begin{array}{c}0.130 \\
{[0.410]}\end{array}$ & $\begin{array}{r}0.138 \\
{[0.381]}\end{array}$ & $\begin{array}{r}0.194 \\
{[0.310]}\end{array}$ & $\begin{array}{l}0.189 \\
{[0.326]}\end{array}$ & $\begin{array}{l}0.257 \\
{[0.204]}\end{array}$ \\
\hline $\begin{array}{l}\text { Angrist-Pischke F test } \\
\text { (Test of excluded instruments) }\end{array}$ & $\begin{array}{r}12.69 \\
{[0.000]}\end{array}$ & $\begin{array}{r}6.99 \\
{[0.000]}\end{array}$ & $\begin{array}{r}23.90 / 15.40 \\
{[0.000 / 0.000]}\end{array}$ & $\begin{array}{r}23.55 / 15.32 \\
{[0.000 / 0.000]}\end{array}$ & $\begin{array}{r}29.12 \\
{[0.000]}\end{array}$ & & & \\
\hline $\begin{array}{l}\text { Hansen J } \\
\qquad \text { (Overidentification test) }\end{array}$ & $\begin{array}{r}1.610 \\
{[0.807]}\end{array}$ & $\begin{array}{r}3.258 \\
{[0.516]}\end{array}$ & $\begin{array}{r}1.432 \\
{[0.698]}\end{array}$ & $\begin{array}{r}0.185 \\
{[0.980]}\end{array}$ & $\begin{array}{r}0.236 \\
{[0.889]}\end{array}$ & $\begin{array}{r}44.16 \\
{[0.631]}\end{array}$ & $\begin{array}{r}40.44 \\
{[0.773]}\end{array}$ & $\begin{array}{r}44.53 \\
{[0.575]}\end{array}$ \\
\hline $\begin{array}{l}\text { Kleinbergen Paap LM test } \\
\text { (Underidentification test) }\end{array}$ & $\begin{array}{r}22.40 \\
{[0.000]}\end{array}$ & $\begin{array}{r}15.28 \\
{[0.009]}\end{array}$ & $\begin{array}{r}21.13 \\
{[0.000]}\end{array}$ & $\begin{array}{r}21.17 \\
{[0.000]}\end{array}$ & $\begin{array}{r}19.61 \\
{[0.000]}\end{array}$ & & & \\
\hline Endogeneity test & $\begin{array}{r}0.082 \\
{[0.774]}\end{array}$ & $\begin{array}{r}0.038 \\
{[0.846]}\end{array}$ & $\begin{array}{r}0.073 \\
{[0.964]}\end{array}$ & $\begin{array}{r}1.131 \\
{[0.568]}\end{array}$ & $\left.\begin{array}{r}1.407 \\
{[0.236]}\end{array}\right]$ & & & \\
\hline Arellano-Bond test for AR1 in 1st differences & & & & & & $\begin{array}{r}-2.559 \\
{[0.011]}\end{array}$ & $\begin{array}{r}-2.524 \\
{[0.012]}\end{array}$ & $\begin{array}{r}-2.559 \\
{[0.011]}\end{array}$ \\
\hline Arellano-Bond test for AR2 in 1st differences & & & & & & $\begin{array}{r}1.233 \\
{[0.218]}\end{array}$ & $\begin{array}{r}1.242 \\
{[0.214]}\end{array}$ & $\begin{array}{r}1.216 \\
{[0.224]}\end{array}$ \\
\hline R squared & 0.280 & 0.504 & 0.280 & 0.379 & 0.378 & & & \\
\hline Observations & 912 & 247 & 912 & 863 & 863 & 870 & 863 & 863 \\
\hline Number of countries & 151 & 36 & 151 & 142 & 142 & 149 & 148 & 148 \\
\hline Number of instruments & 5 & 5 & 5 & 5 & 3 & 61 & 61 & 60 \\
\hline
\end{tabular}

2SLS regressions with clustered standard errors, country and time fixed effects and instruments listed below.

System GMM with fixed time effects, Windmeijer finite sample correction and external instruments listed below.

Instruments (1)-(4): Number of Tibet Support Groups (lagged), Dalai Lama visit dummy (current and lagged) and Duration of Dalai Lama visit (in days, current and lagged)

Instruments (5)-(8): Number of Tibet Support Groups (lagged), Dalai Lama visit dummy (current) and Duration of Dalai Lama visit (in days, current)

* significant at $10 \%$; ${ }^{* *}$ significant at $5 \%$; ${ }^{* * *}$ significant at $1 \%$ 
Table 5.1 Results by product groups: Exports to China and Dalai Lama meetings of political leaders (all countries, 2002-2008)

\begin{tabular}{l|c|c|c|c|c|c|c|c} 
& \multicolumn{9}{c}{ World 2002-2008 } \\
Product Group (SITC) & \% trade & \multicolumn{2}{|c|}{ Fixed Effects } & \multicolumn{2}{|c|}{ FGLS AR(1) } & Obs. & Countries \\
\hline Food, live animals (0) & $1.7 \%$ & -0.197 & {$[0.283]$} & $-0.107 *$ & {$[0.075]$} & 710 & 124 \\
Beverages and Tobacco (1) & $0.2 \%$ & 0.181 & {$[0.545]$} & 0.115 & {$[0.319]$} & 467 & 91 \\
Crude materials, inedible, except fuels (2) & $12.1 \%$ & -0.140 & {$[0.328]$} & $-0.116^{* * *}$ & {$[0.003]$} & 840 & 140 \\
Mineral fuels, lubricants and related materials (3) & $7.8 \%$ & -0.432 & {$[0.275]$} & $-0.352^{* * *}$ & {$[0.000]$} & 481 & 84 \\
Animal and vegetable oils, fats and waxes (4) & $1.0 \%$ & -0.206 & {$[0.661]$} & -0.046 & {$[0.620]$} & 349 & 69 \\
Chemicals and related products, n.e.s. (5) & $12.4 \%$ & -0.096 & {$[0.593]$} & -0.049 & {$[0.194]$} & 722 & 125 \\
Manufactured goods classified chiefly by material (6) & $13.3 \%$ & -0.031 & {$[0.874]$} & -0.032 & {$[0.499]$} & 800 & 132 \\
Machinery and transport equipment (7) & $41.0 \%$ & $-0.605 * * *$ & {$[0.000]$} & $-0.359 * * *$ & {$[0.000]$} & 756 & 129 \\
Miscellaneous manufactured articles (8) & $7.3 \%$ & -0.232 & {$[0.291]$} & $-0.105 *$ & {$[0.054]$} & 754 & 128 \\
Commodities and transactions not classified elsewhere (9) & $2.2 \%$ & -0.294 & {$[0.324]$} & -0.037 & {$[0.675]$} & 504 & 100 \\
\hline
\end{tabular}

Note: All regressions with country and time fixed effects.

Robust $\mathrm{p}$ values in brackets; ${ }^{*}$ significant at $10 \%$; ${ }^{* *}$ significant at $5 \%$; ${ }^{* * *}$ significant at $1 \%$

Standard errors in OLS Fixed Effects regressions are adjusted for clustering across partner countries.

FGLS regressions are corrected for cross-sectional heteroskedasticity across panels and first order autocorrelation.

$\%$ trade denotes the average share of each SITC product group in total exports to China in 2002-2008

Table 5.2 Results by product groups: Exports to China and Dalai Lama meetings of political leaders (European countries, 2002-2008)

\begin{tabular}{|c|c|c|c|c|c|c|c|}
\hline \multirow{3}{*}{$\begin{array}{l}\text { Product Group (SITC) } \\
\text { Food, live animals (0) }\end{array}$} & \multicolumn{7}{|c|}{ Europe 2002-2008 } \\
\hline & \multirow{2}{*}{$\begin{array}{c}\% \text { trade } \\
1.3 \%\end{array}$} & \multicolumn{2}{|c|}{ Fixed Effects } & \multicolumn{2}{|c|}{ FGLS AR(1) } & \multirow{2}{*}{$\frac{\text { Obs. }}{213}$} & \multirow{2}{*}{$\frac{\text { Countries }}{33}$} \\
\hline & & $-0.539 * *$ & [0.029] & -0.160 & [0.110] & & \\
\hline Beverages and Tobacco (1) & $0.4 \%$ & 0.126 & [0.784] & 0.279 & [0.177] & 190 & 32 \\
\hline Crude materials, inedible, except fuels (2) & $5.7 \%$ & -0.052 & [0.742] & $-0.114^{*}$ & [0.084] & 242 & 36 \\
\hline Mineral fuels, lubricants and related materials (3) & $1.0 \%$ & -0.132 & [0.695] & $-0.228^{*}$ & [0.087] & 191 & 29 \\
\hline Animal and vegetable oils, fats and waxes (4) & $0.1 \%$ & -0.280 & [0.715] & 0.100 & [0.668] & 142 & 26 \\
\hline Chemicals and related products, n.e.s. (5) & $9.5 \%$ & -0.004 & [0.985] & $-0.143 * *$ & [0.011] & 237 & 36 \\
\hline Manufactured goods classified chiefly by material (6) & $12.5 \%$ & -0.306 & [0.187] & -0.103 & [0.171] & 241 & 36 \\
\hline Machinery and transport equipment (7) & $58.3 \%$ & $-0.396 * *$ & [0.025] & $-0.286 * * *$ & {$[0.000]$} & 246 & 36 \\
\hline Miscellaneous manufactured articles (8) & $7.0 \%$ & -0.191 & [0.304] & -0.059 & [0.262] & 245 & 36 \\
\hline Commodities and transactions not classified elsewhere (9) & $3.6 \%$ & 0.060 & {$[0.820]$} & 0.074 & {$[0.610]$} & 177 & 30 \\
\hline
\end{tabular}

Note: All regressions with country and time fixed effects.

Robust p values in brackets; ${ }^{*}$ significant at $10 \%$; ${ }^{* *}$ significant at $5 \%$; $* * *$ significant at $1 \%$

Standard errors in OLS Fixed Effects regressions are adjusted for clustering across partner countries.

FGLS regressions are corrected for cross-sectional heteroskedasticity across panels and first order autocorrelation.

$\%$ trade denotes the average share of each SITC product group in total exports to China in 2002-2008 
Figure 1 Geographic allocation of Dalai Lama visits (1991-2008)

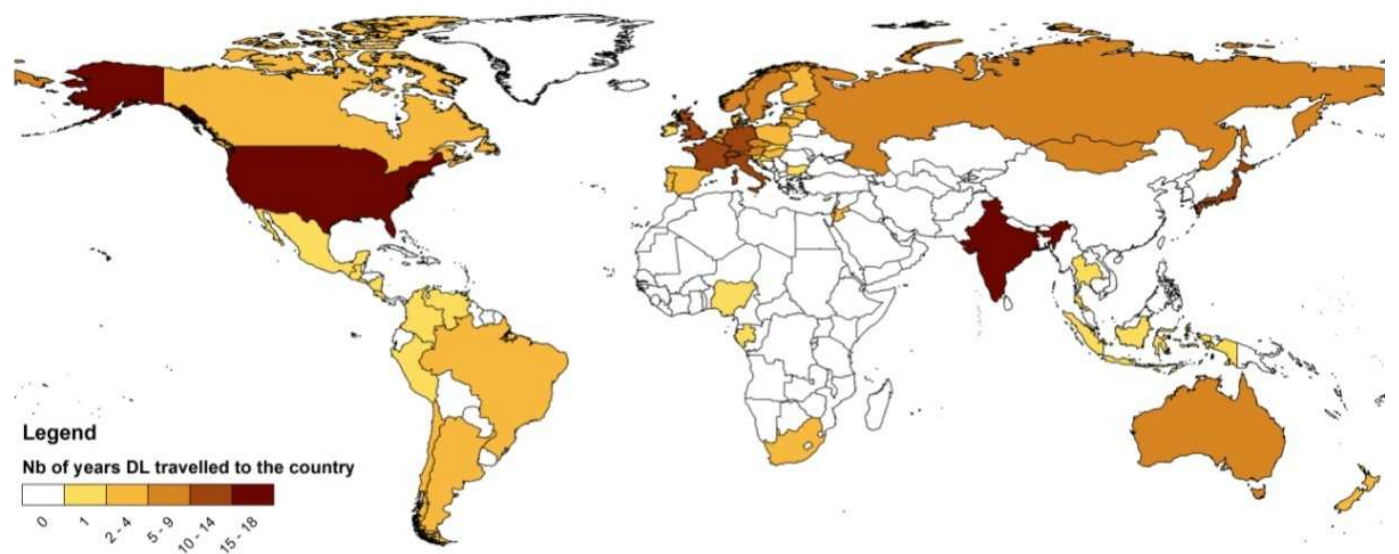

Source: Authors' calculations

Figure 2 Geographic allocation of Dalai Lama receptions by government officials (1991-2008)

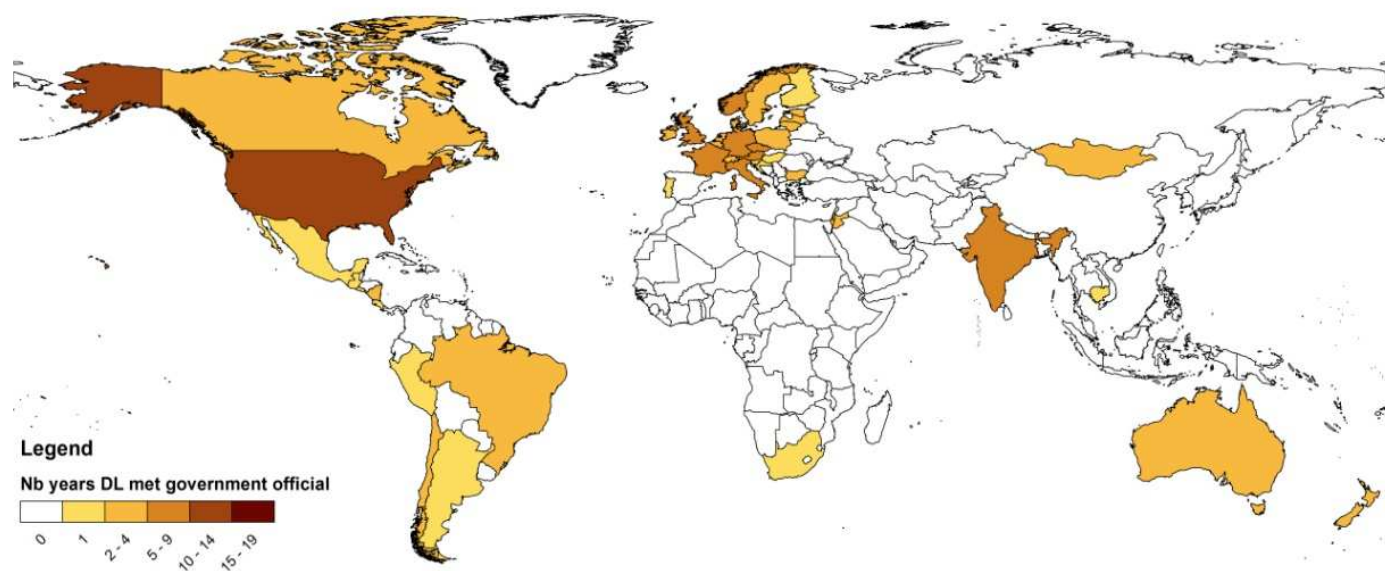

Source: Authors' calculations

Figure 3 Geographic allocation of Dalai Lama receptions by political leaders (1991-2008)

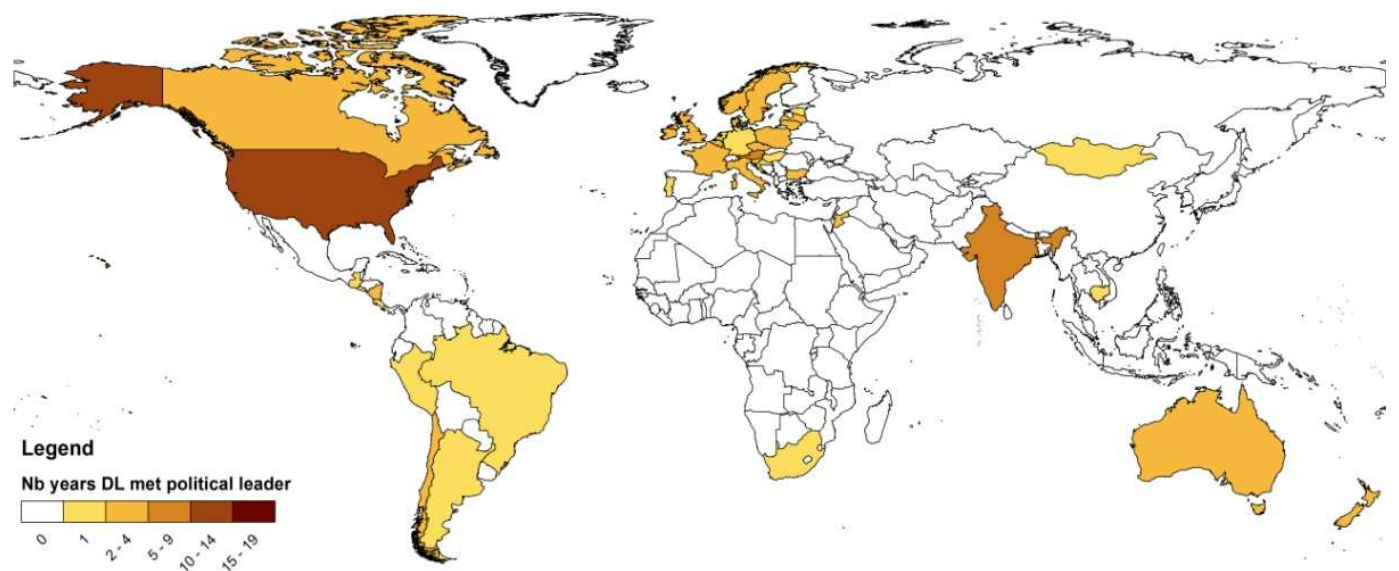

Source: Authors' calculations 
Table A1 Dalai Lama meetings ranked by dignitary met

Information on the dignitaries met by the Dalai Lama is obtained from the webpage of the Office of His Holiness the 14th Dalai Lama. Dignitaries are grouped into the following four categories:

\section{Political Leaders}

- Head of state, president, king, pope, acting president

- Head of government, prime minister, chancellor

\section{Government Members}

- All dignitaries listed under "Political Leaders"

- Vice president, vice chancellor

- Foreign minister

- Minister, member of government

\section{National Officials}

- All dignitaries listed under "Government Members"

- Speaker of parliament, (vice) president of parliament

\section{All dignitaries}

- All dignitaries listed under "National Officals"

- Former president, former prime minister, first lady

- Regional leader, governor, head of province

- Party leader, leader of parliamentary group

- Other religious leader, other royals

- Deputies, ambassadors, special envoys

- Nobel prize laureates, scientists 
Table A2 Data description

\begin{tabular}{|c|c|c|}
\hline Variable & Description & Data source \\
\hline Total exports & $\begin{array}{l}\text { Log of total exports to China in given year from partner } \\
\text { country (SITC Rev. 3) (in current US\$) }\end{array}$ & Comtrade via WITS \\
\hline Food, life animals & $\begin{array}{l}\text { Log of exports of Food, life animals in given year from } \\
\text { partner country to China (SITC Group 0) (in current US\$) }\end{array}$ & Comtrade via WITS \\
\hline Beverages and Tobacco & $\begin{array}{l}\text { Log of exports of Beverages and Tobacco in given year from } \\
\text { partner country to China (SITC Group 1) (in current US\$) }\end{array}$ & Comtrade via WITS \\
\hline $\begin{array}{l}\text { Crude materials, inedible, } \\
\text { except fuels }\end{array}$ & $\begin{array}{l}\text { Log of exports of Crude materials, inedible, except fuels in } \\
\text { given year from partner country to China (SITC Group 2) (in } \\
\text { current US } \$ \text { ) }\end{array}$ & Comtrade via WITS \\
\hline $\begin{array}{l}\text { Mineral fuels, lubricants } \\
\text { and related materials }\end{array}$ & $\begin{array}{l}\text { Log of exports of Mineral fuels, lubricants and related } \\
\text { materials in given year from partner country to China (SITC } \\
\text { Group 3) (in current US } \$ \text { ) }\end{array}$ & Comtrade via WITS \\
\hline $\begin{array}{l}\text { Animal and vegetable oils, } \\
\text { fats and waxes }\end{array}$ & $\begin{array}{l}\text { Log of exports of Animal and vegetable oils, fats and waxes } \\
\text { in given year from partner country to China (SITC Group 4) } \\
\text { (in current US\$) }\end{array}$ & Comtrade via WITS \\
\hline $\begin{array}{l}\text { Chemicals and related } \\
\text { products, n.e.s. }\end{array}$ & $\begin{array}{l}\text { Log of exports of Chemicals and related products, n.e.s. in } \\
\text { given year from partner country to China (SITC Group 5) (in } \\
\text { current US } \$ \text { ) }\end{array}$ & Comtrade via WITS \\
\hline $\begin{array}{l}\text { Manufactured goods } \\
\text { classified chiefly by } \\
\text { material }\end{array}$ & $\begin{array}{l}\text { Log of exports of Manufactured goods classified chiefly by } \\
\text { material in given year from partner country to China (SITC } \\
\text { Group 6) (in current US } \$ \text { ) }\end{array}$ & Comtrade via WITS \\
\hline $\begin{array}{l}\text { Machinery and transport } \\
\text { equipment }\end{array}$ & $\begin{array}{l}\text { Log of exports of Machinery and transport equipment in given } \\
\text { year from partner country to China (SITC Group 7) (in current } \\
\text { US\$) }\end{array}$ & Comtrade via WITS \\
\hline $\begin{array}{l}\text { Miscellaneous } \\
\text { manufactured articles }\end{array}$ & $\begin{array}{l}\text { Log of exports of Miscellaneous manufactured articles in } \\
\text { given year from partner country to China (SITC Group 8) (in } \\
\text { current US\$) }\end{array}$ & Comtrade via WITS \\
\hline $\begin{array}{l}\text { Commodities and } \\
\text { transactions not classified } \\
\text { elsewhere in the SITC }\end{array}$ & $\begin{array}{l}\text { Log of exports of Commodities and transactions not } \\
\text { classified elsewhere in the SITC in given year from partner } \\
\text { country to China (SITC Group 9) (in current US\$) }\end{array}$ & Comtrade via WITS \\
\hline
\end{tabular}




\begin{tabular}{|c|c|c|}
\hline Dalai Lama meeting & $\begin{array}{l}\text { Binary dummy variable that is } 1 \text { if the Dalai Lama was } \\
\text { received in partner country } \\
\text { - By the head of state or head of government } \\
\text { - By a member of government (additionally includes } \\
\text { all ministers) } \\
\text { - By a national official representative (additionally } \\
\text { includes speakers of parliament) } \\
\text { By any dignitary listed by the Office of the Dalai } \\
\text { Lama (additionally includes former heads of state or } \\
\text { government, regional leaders, party leaders, } \\
\text { scientists, special envoys and religious leaders, } \\
\text { among others) }\end{array}$ & $\begin{array}{l}\text { Office of His Holiness the } \\
14^{\text {th }} \text { Dalai Lama }\end{array}$ \\
\hline Dalai Lama visits country & $\begin{array}{l}\text { Binary dummy variable that is } 1 \text { if the Dalai Lama travelled to } \\
\text { partner country }\end{array}$ & $\begin{array}{l}\text { Office of His Holiness the } \\
14^{\text {th }} \text { Dalai Lama }\end{array}$ \\
\hline $\begin{array}{l}\text { Duration of Dalai Lama } \\
\text { visit }\end{array}$ & Number of days the Dalai Lama visited a partner country & $\begin{array}{l}\text { Office of His Holiness the } \\
14^{\text {th }} \text { Dalai Lama }\end{array}$ \\
\hline Tibet Support Groups & $\begin{array}{l}\text { Number of Tibet Support Groups (TSG) in partner country } \\
\text { and year (based on information on year of foundation of } \\
\text { TSG) }\end{array}$ & $\begin{array}{lr}\text { Central } & \text { Tibetan } \\
\text { Administration, } & \text { own } \\
\text { research } & \end{array}$ \\
\hline Log of GDP & $\begin{array}{l}\text { Log of gross domestic product of partner country in current } \\
\text { US dollars }\end{array}$ & $\begin{array}{l}\text { World Development } \\
\text { Indicators }\end{array}$ \\
\hline Log of population & Log of population size of partner country & $\begin{array}{l}\text { World Development } \\
\text { Indicators }\end{array}$ \\
\hline Log of exchange rate & $\begin{array}{l}\text { Log of nominal exchange rate index (local currency unit per } \\
\text { Yuan) }(2000=100) \text {, which is calculated as the ratio of the } \\
\text { official exchange rate LCU per US } \$ \text { and the official exchange } \\
\text { rate US } \$ \text { per Chinese yuan }\end{array}$ & $\begin{array}{l}\text { World Development } \\
\text { Indicators }\end{array}$ \\
\hline Other exports / GDP & $\begin{array}{l}\text { Total exports to all countries except China (as a share of } \\
\text { GDP) }\end{array}$ & Comtrade via WITS \\
\hline Log of tariff rate & Log of trade-weighted bilateral tariff rate & $\begin{array}{l}\text { UNCTAD TRAINS via } \\
\text { WITS }\end{array}$ \\
\hline UNGA voting alignment & $\begin{array}{l}\text { Number of times that a trading partner had the same voting } \\
\text { behavior as China in the United General Assembly (as a } \\
\text { share of all voting instances) }\end{array}$ & $\begin{array}{l}\text { Voeten and Merdzanovic } \\
\text { (2009) }\end{array}$ \\
\hline
\end{tabular}

Note: All data is available for 1991-2008. Information on Dalai Lama meetings and Dalai Lama visits was completed with information provided on www.buddhismtoday.com. 
Table A3 Descriptive Statistics

\begin{tabular}{|c|c|c|c|c|c|}
\hline Variable & Obs & Mean & Std. Dev. & Min & Max \\
\hline \multicolumn{6}{|l|}{ Exports to China (in million US\$) } \\
\hline Total & 2066 & 1780 & 7560 & 0 & 125000 \\
\hline Food, life animals & 1564 & 53 & 156 & 0 & 2320 \\
\hline Beverages and Tobacco & 963 & 9 & 37 & 0 & 451 \\
\hline Crude materials, inedible, except fuels & 1770 & 267 & 1190 & 0 & 20500 \\
\hline Mineral fuels, lubricants and related materials & 1028 & 278 & 979 & 0 & 11800 \\
\hline Animal and vegetable oils, fats and waxes & 706 & 64 & 267 & 0 & 3900 \\
\hline Chemicals and related products, n.e.s. & 1524 & 282 & 1230 & 0 & 17200 \\
\hline Manufactured goods classified chiefly by material & 1768 & 286 & 1200 & 0 & 19700 \\
\hline Machinery and transport equipment & 1649 & 919 & 4200 & 0 & 62900 \\
\hline Miscellaneous manufactured articles & 1630 & 132 & 768 & 0 & 13900 \\
\hline Commodities and transactions not classified elsewhere & 1042 & 82 & 445 & 0 & 7490 \\
\hline \multicolumn{6}{|l|}{ Variable of interest } \\
\hline Dalai Lama meeting with political leader in t or t-1 & 2066 & 0.07 & 0.26 & 0 & 1 \\
\hline Dalai Lama meeting with government member in t or $\mathrm{t}-1$ & 2066 & 0.11 & 0.31 & 0 & 1 \\
\hline Dalai Lama meeting with national official in t or t-1 & 2066 & 0.11 & 0.31 & 0 & 1 \\
\hline Dalai Lama meeting with all dignitaries in t or t-1 & 2066 & 0.12 & 0.33 & 0 & 1 \\
\hline Dalai Lama visits country in t or t-1 & 2066 & 0.16 & 0.37 & 0 & 1 \\
\hline \multicolumn{6}{|l|}{ Instruments } \\
\hline Number of Tibet Support Groups & 2066 & 0.79 & 2.83 & 0 & 31 \\
\hline Dalai Lama visit dummy & 2066 & 0.10 & 0.30 & 0 & 1 \\
\hline Duration of Dalai Lama visit (in days) & 2066 & 1.36 & 7.68 & 0 & 124 \\
\hline \multicolumn{6}{|l|}{ Controls } \\
\hline GDP (in million US\$) & 2066 & 282000 & 1060000 & 106 & 14200000 \\
\hline Population (in million) & 2066 & 35 & 102 & 0 & 1140 \\
\hline Exchange rate $(2000=100)$ & 2066 & 1.28 & 11.45 & 0.00 & 508.66 \\
\hline Other exports / GDP & 2053 & 27.15 & 20.74 & 0.31 & 176.26 \\
\hline Tariff rate & 1983 & 11.80 & 11.62 & 0.00 & 95.50 \\
\hline UNGA voting alignment with China & 2041 & 78.89 & 12.88 & 13.64 & 96.10 \\
\hline
\end{tabular}




\section{Table A4 List of countries}

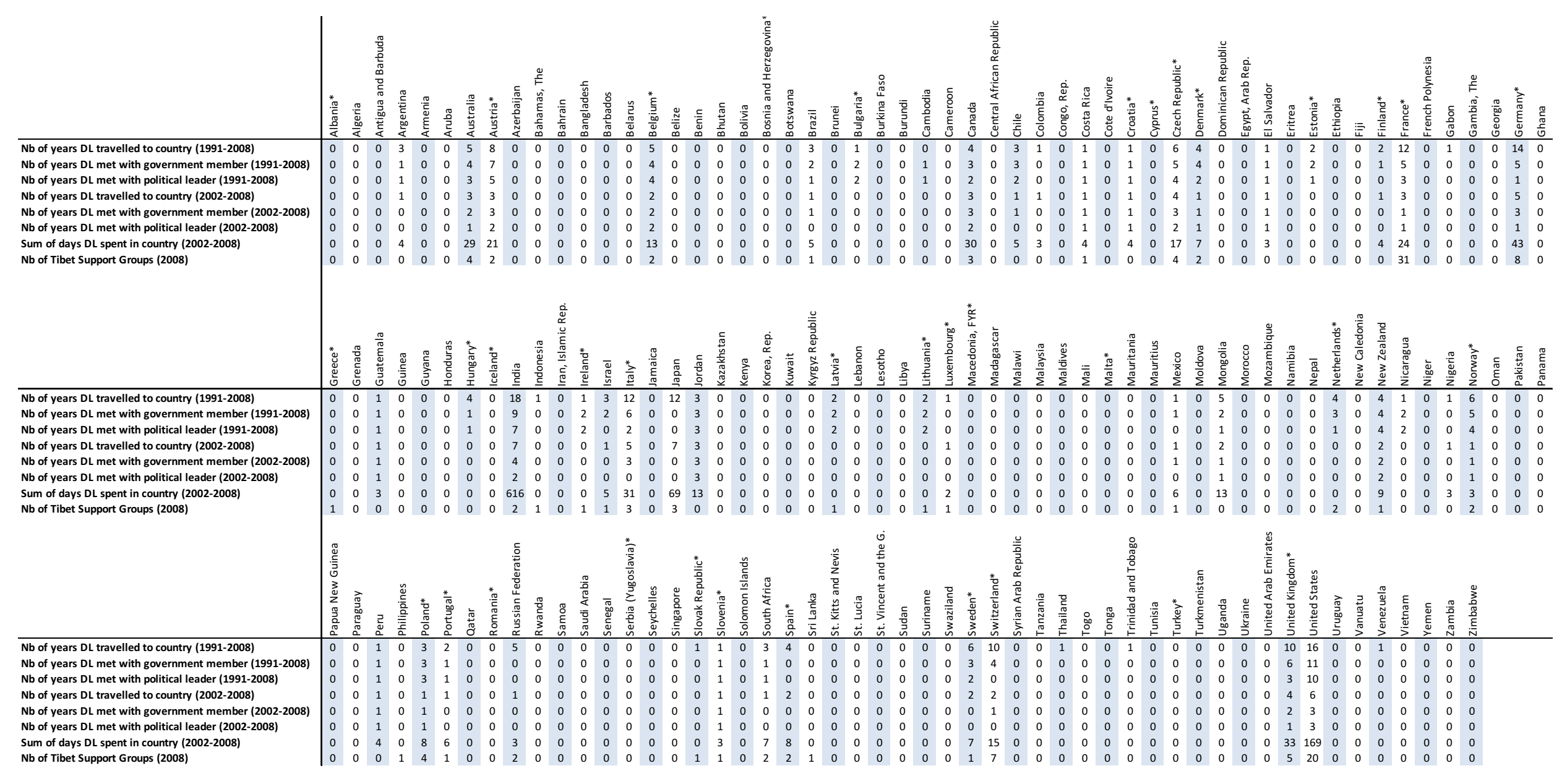

Note: All countries included in the European subsample are marked with an asterix $\left(^{*}\right)$. 